\title{
O gênero Anthurium (Araceae) no estado do Paraná - Brasil
}

\author{
The genus Anthurium (Araceae) in Paraná State - Brazil
}

\author{
Lilien Cristhiane Ferneda Rocha ${ }^{1,5}$, Eric de Camargo Smidt ${ }^{2}$, Marcus Alberto Nadruz Coelho ${ }^{3}$, \\ Lívia Godinho Temponi ${ }^{4}$
}

\begin{abstract}
Resumo
O trabalho apresenta a flora do gênero Anthurium (Araceae) no estado do Paraná. Ocorrem 12 espécies de Anthurium no estado: A. acutum, A. comtum, A. gaudichaudianum, A. hatschbachii, A. lacerdae, A. loefgrenii, A. marense, A. pentaphyllum, A. scandens subsp. scandens, A. sellowianum, A. sinuatum e A. urvilleanum. As espécies estão distribuídas exclusivamente na Floresta Ombrófila Densa, com exceção de A. loefgrenii que ocorre também em restinga arbórea, de A. gaudichaudianum que ocorre também no Cerrado e transição entre Floresta Ombrófila Densa e Mista, e de A. sinuatum que ocorre apenas na Floresta Estacional Semidecidual. Há cinco espécies ameaçadas de extinção para o estado: A. hatschbachii e A. urvilleanum (Criticamente em Perigo), A. sinuatum (Em Perigo) e A. lacerdae e A. marense (Vulneráveis). Relata-se como novidades morfológicas: a presença de tricomas no eixo axilar do ovário em A. hatschbachii, A. lacerdae, A. marense, A. sinuatum e A. urvilleanum; e a placentação do tipo axial apical para $A$. acutum. São apresentadas chave de identificação, descrições, pranchas de fotos e ilustrações, distribuição geográfica, comentários taxonômicos e o estado de conservação para todas as espécies. Palavras-chave: flora, levantamento florístico, taxonomia.
\end{abstract}

\begin{abstract}
This work presents the flora of the genus Anthurium (Araceae) in Paraná State. Twelve species of Anthurium occur in the state: A. acutum, A. comtum, A. gaudichaudianum, A. hatschbachii, A. lacerdae, A. loefgrenii, A. marense, A. pentaphyllum, A. scandens subsp. scandens, A. sellowianum, A. sinuatum and A. urvilleanum. The species are distributed just only in dense rain forest, except for $A$. loefgrenii which also occurs in arboreal restinga, A. gaudichaudianum also found in the cerrado and the transition between dense and mixed rain forest, and $A$. sinuatum that occurs only in semideciduous forest. There are five endangered species in the state: $A$. hatschbachii and A. urvilleanum (Critically Endangered), A. sinuatum (Endangered) and A. lacerdae and $A$. marense (Vulnerable). This work also presents morphological novelties: the presence of trichomes in the axillary axis of the ovary of $A$. hatschbachii, A. lacerdae, A. marense, A. sinuatum and A. urvilleanum, and apical-axial placentation type for $A$. acutum. Identification key, descriptions, photos, illustrations, geographic distribution, taxonomic remarks and conservation status are given for all species.
\end{abstract}

Key words: flora, floristic survey, taxonomy.

\section{Introdução}

Anthurium Schott é o maior gênero da família Araceae com 905 espécies (Boyce \& Croat 2012), tendo como centro de distribuição a região Neotropical (Mayo et al. 1997). No Brasil ocorrem
138 espécies, das quais 101 são consideradas endêmicas ao território nacional (Coelho \& Temponi 2013). O gênero possui uma grande variedade de formas de vida, morfologia foliar, padrões de nervação foliar e cor de flores e frutos (Mayo et al. 1997). Suas principais características

Este artigo possui material adicional em sua versão eletrônica

\footnotetext{
${ }^{1}$ Universidade Federal do Paraná, Programa de Pós-Graduação em Botânica, Centro Politécnico, Depto. Botânica, Av. Coronel Francisco Herácito dos Santos, 100 Jardim das Américas, Curitiba, PR, Brasil.

${ }^{2}$ Universidade Federal do Paraná, Centro Politécnico, Av. Coronel Francisco Herácito dos Santos, 100, Jardim das Américas, Curitiba, PR, Brasil.

${ }^{3}$ Instituto de Pesquisas Jardim Botânico do Rio de Janeiro, R. Pacheco Leão, 915, Jardim Botânico, Rio de Janeiro, RJ, Brasil.

${ }^{4}$ Universidade Estadual do Oeste do Paraná, Centro de Ciências Biológicas e da Saúde, R. Universitária, 2069, Cascavel, PR, Brasil.

${ }^{5}$ Autor para correspondência: liliencristhiane@hotmail.com.
} 
distintivas são as inflorescências solitárias; espata livre; pecíolo geniculado apicalmente, com formato variável em secção transversal; presença de nervura coletora; flores bissexuais, perigoniadas, ovário 2-locular e fruto do tipo baga (Mayo et al. 1997; Croat 1994).

O trabalho pioneiro da Flora Analítica do Paraná (Angely 1965) cita oito espécies de Anthurium para o estado: A. acutum N.E.Br., $A$. gaudichaudianum Kunth, A. harrissi (Graham) G. Don., A. harrissi var. beyrichianum (Kunth) Engl., A. lacerdae Reitz, A. scandens (Aubl.) Engl., A. undatum Schott e $A$. willdenowii Kunth, porém não há indicação de voucher para as espécies. Já a Lista de Espécies da Flora do Brasil (Coelho \& Temponi 2013) aponta 15 táxons do gênero para o estado: $A$. acutum, A. clavigerum Poepp., A. comtum Schott, A. coriaceum G.Don, A. gaudichaudianum, $A$. hatschbachii E.G.Gonç., A. loefgrenii Engl., $A$. marense K.Krause, A. maximilianii Schott, $A$. pentaphyllum var. pentaphyllum, A. scandens subsp. scandens, A. sellowianum Kunth, $A$. sinuatum Benth. ex Schott, A. undatum e $A$. urvilleanum Schott. Na única listagem de espécies ameaçadas de extinção no Paraná foram citadas três espécies de Anthurium: A. kunthii Poepp., A. olfersianum Kunth e A. parvum N. E. Br. (Hatschbach \& Ziller 1995), as quais não ocorrem no estado segundo as demais listagens (Angely 1965; Coelho \& Temponi 2013).

Diante da divergência entre autores sobre a riqueza de espécies do gênero no Paraná e considerando a ausência de um tratamento taxonômico de Anthurium para o estado, o objetivo deste trabalho foi levantar a flora do gênero para o Paraná. São apresentadas chave de identificação, descrições, ilustrações, distribuição geográfica, floração, frutificação e a classificação das espécies quanto ao seu estado de conservação (IUCN 2012, 2013).

\section{Material e Métodos}

O estado do Paraná com 199.316,694km² e localizado na região sul do Brasil, possui uma vegetação muito diversificada formada por cinco unidades fitogeográficas: Floresta Ombrófila Densa, Floresta Ombrófila Mista, Floresta Estacional Semidecidual, Estepe (campos) e Savana (cerrado) (IBGE 2010; Roderjan et al. 2002).

Foram realizadas 50 expedições de coleta no período de julho de 2012 a novembro de 2013 , organizadas de forma a amostrar todas as unidades fitogeográficas do estado, sendo visitados 27 municípios. Além disso, foram analisadas 380 exsicatas depositadas na coleção do herbário da Universidade Estadual do Oeste do Paraná (UNOP) e dos herbários: BHCB, EFC, FLOR, FUEL, FURB, HBR, HCF, HUCP, HUEM, HUPG, JOI, MBM, UPCB, R, RB, SP, SPF, UEC (Thiers continuously updated).

As coletas foram realizadas de acordo com a metodologia descrita para Araceae por Croat (1985) e herborizadas de acordo com técnicas usuais (Bridson \& Forman 2004). O material foi depositado nos herbários da Universidade Federal do Paraná (UPCB) e da Universidade Estadual do Oeste do Paraná (UNOP).

Para as identificações dos taxa foram utilizadas a literatura especializada, comparação com a fotografia e descrições dos espécimes tipo, ou, com o material herborizado previamente identificado. A grafia dos nomes científicos e dos autores das espécies foi citada segundo The International Plant Names Index (IPNI 2010). A terminologia utilizada nas descrições foi baseada em Stearn (2004) e complementada com Croat \& Bunting (1979) e Radford et al. (1974).

Os dados de distribuição geográfica foram obtidos nas etiquetas dos materiais herborizados, além de literatura específica (Coelho et al. 2009; Coelho \& Temponi 2013; Madison 1978; Sheffer et al. 1980). Para representar o material selecionado foi escolhida uma coleta de cada município da área de ocorrência, assim como para a confecção dos mapas de distribuição.

A classificação quanto ao estado de conservação das espécies seguiu as Diretrizes de Aplicação dos Critérios da Lista Vermelha da IUCN para Níveis Regionais e Nacionais (IUCN 2012, 2013).

\section{Resultados e Discussão}

O presente trabalho permitiu a atualização das listagens de Anthurium existentes para o Paraná, as quais foram baseadas apenas em material de herbário, e que diverge dessa no número e identidade das espécies. Confirmou-se a presença de 12 espécies do gênero no estado: A. acutum, A. comtum, A. gaudichaudianum, $A$. hatschbachii, A. lacerdae, A. loefgrenii, A. marense, A. pentaphyllum, A. scandens subsp. scandens, $A$. sellowianum, A. sinuatum e A. urvilleanum.

A análise dos espécimes demonstrou que alguns nomes verificados nos herbários referem- 
se a sinônimos ou identificações equivocadas, gerando uma proliferação de nomes. Dentre os materiais citados nos outros trabalhos que não foram confirmados no presente estudo, tratam-se de determinações equivocadas: $A$. harrisii e $A$. harrisii var. beyrichianum que foi redeterminado como A. comtum ou A. sellowianum; A. olfersianum redeterminado como $A$. loefgrenii; $A$. maximilianii redeterminado como $A$. hatschbachii; $A$. coriaceum redeterminado como $A$. lacerdae; e $A$. kunthii redeterminado como $A$. sinuatum. A espécie $A$. undatum é atualmente sinônimo de $A$. pentaphyllum. Durante as visitas a herbários e as coletas não foi encontrado voucher de $A$. parvum para o Paraná. Deste modo, acreditamos que ela não ocorra no estado. Por fim, A. willdenowii é uma espécie exótica que não ocorre naturalmente no Brasil e o registro de $A$. clavigerum para o Paraná na Lista de Espécies da Flora do Brasil foi um equívoco no nome do estado na etiqueta do herbário. Na verdade A. clavigerum ocorre no estado do Pará, sendo indicada a atualização da lista com essa informação.

No Paraná as espécies se distribuem em duas regiões distintas: apenas $A$. sinuatum ocorre em Floresta Estacional Semidecidual no extremo oeste do estado, e as demais espécies ocorrem na Floresta Ombrófila Densa ou Mista, Cerrado e Restinga na região leste.

Cinco espécies foram classificadas como ameaçadas de extinção de acordo com os critérios da IUCN (2013): A. hatschbachii e A. urvilleanum (Criticamente em Perigo), A. lacerdae e A. marense (Vulneráveis), e A. sinuatum (Em Perigo). $A$. hatschbachii é a única das espécies ameaçadas no estado que ocorre dentro de uma propriedade particular que não é uma área protegida.

Alguns autores propuseram a descrição mais detalhada de estruturas florais do gênero e indicaram que elas podem ser informativas taxonomicamente (Croat \& Bunting, 1979; Temponi, 2006). Os caracteres florais analisados que se mostraram informativos taxonomicamente foram: o tamanho dos estames e ovário, a placentação, o número de óvulos por lóculo e a presença de tricomas no eixo axilar do ovário.

\section{Tratamento taxônomico \\ Anthurium Schott, Wiener Zeitschrift für} Kunst III. 828. 1829.

Ervas perenes; terrestres, epífitas, rupícolas ou saxícolas; caule ereto, escandente ou reptante; entrenós curtíssimos a alongados. Catafilos e profilos persistentes ou decíduos, inteiros ou marcescentes. Pecíolo geniculado apicalmente, de formato variado em secção transversal. Lâmina foliar membranácea, cartácea ou coriácea; simples ou composta, formato muito variado; com ou sem pontuações glandulares; nervuras laterais geralmente formando nervuras coletoras marginais, nervação terciária reticular. Inflorescência terminal, solitária. Pedúnculo curto a geralmente alongado, cilíndrico, com ou sem carenas. Espata persistente, raro decídua; lanceolada, oblonga ou navicular; ereta, patente ou deflexa, formando ângulo agudo, reto ou obtuso com o pecíolo. Espádice séssil a longo estipitado; cilíndrico a cônico, às vezes afilando no ápice. Flores bissexuais; 4 tépalas, dispostas em 2 verticilos decussados; 4 estames, livres, filamentos achatados, anteras rimosas; ovário 2-locular; 1-2-óvulos lóculo; placentação axial ou axial apical; região estilar inconspícua a atenuada; estigma elíptico ou globoso, secretando gotículas de néctar em antese. Bagas globosas, obovoides, oblongas a obcônicas, maduras exsertas as tépalas, cor variada. Sementes formato variável, envolvidas por uma mucilagem.

\section{Chave de identificação para as espécies de Anthurium do estado do Paraná}

1. Plantas geralmente hemiepífitas, raro terrestres ou rupícolas; lâmina foliar composta ........................2

2. Catafilos e profilos desmanchando em fibras; margem dos folíolos inteira; pedúnculo com menos da metade do comprimento do pecíolo, infrutescência ereta ............ 8. Anthurium pentaphyllum

2'. Catafilos e profilos inteiros, raro desmanchando em fibras na base; margem dos folíolos sinuada; pedúnculo com mais da metade ou comprimento igual ao do pecíolo, infrutescência pendente ...

11. Anthurium sinuatum

1'. Plantas geralmente terrestres, epífitas ou rupícolas; lâmina foliar inteira........................................ 3

3. Lâmina foliar de base cordada, sagitada ou hastada ...........................................................4

4. Lâmina foliar de base cordada; presença de pontuações glandulares na lâmina foliar, pedúnculo e genículo 4. Anthurium hatschbachii 
4'. Lâmina foliar sagitada ou hastada; pontuações glandulares ausentes........1. Anthurium acutum

3'. Lâmina foliar com base aguda, arredondada, estreito-cuneada, longo-cuneada, obtusa ou truncada....... 5

5. Lâmina foliar com pontuações glandulares visíveis a olho nu .................................................. 6

6. Epífita; estípite ausente a raro presente, quando presente até $0,2 \mathrm{~cm}$ compr.; bagas alvas ou alvo-arroxeadas ....................................................... Anthurium scandens subsp. scandens

6'. Terrestre ou rupícola; estípite presente com 1-5,7 cm compr.; bagas verdes

7. Anthurium marense

5'. Lâmina foliar sem pontuações glandulares, quando presentes não visíveis a olho nu ... 7

7. Lâmina foliar coriácea, 2 nervuras coletoras, espata coriácea e revoluta, 6-15 flores na espiral principal, 10-19 flores na espiral secundária 5. Anthurium lacerdae

7'. Lâmina foliar membranácea ou cartácea, 1 nervura coletora, espata membranácea ou cartácea, não revoluta, 3-8 flores na espiral principal, 4-11 flores na espiral secundária ................... 8

8. Catafilos inteiros e persistentes; nervação secundária inconspícua; espádice geralmente longo estipitada, estípite $(0,1) 0,5-2,5 \mathrm{~cm}$ compr.; bagas amarelas, raro alaranjadas ou esverdeadas

3. Anthurium gaudichaudianum

8'. Catafilos e desmanchando em fibras em senescência e caducos para a base do caule; nervação secundária evidente; espádice séssil a raro estipitado, estípite até $0,6 \mathrm{~cm}$ compr.; bagas verdes, vináceas ou alvas na base e verde à verde nigrescente no ápice, às vezes translúcidas

9. Lâmina foliar verde-amarelada abaxialmente; espata geralmente decídua em antese ou pós-antese; espádice cor-de-palha a pardacento em pós-antese e frutificação...

2. Anthurium comtum

9'. Lâmina foliar não amarelada abaxialmente; espata persistente a apenas ocasionalmente decídua na frutificação; espádice castanho, verde, verde-amarelado, vináceo, roxo a roxo-acastanhado em pós-antese e frutificação 10

10. Catafilos e profilos jovens alvo-avermelhados a verdes; pecíolo verde com base avermelhada a verde; espádice levemente afilando no ápice; bagas totalmente vináceas ou vináceas pelo menos no ápice.

12. Anthurium urvilleanum

10'. Catafilos e profilos jovens verdes, verdes com a base creme ou alvescentes, a raro verde-arroxeados; pecíolo verde a verde com base alvescente; espádice não afilando no ápice; bagas totalmente verdes a alvos na base e verde a verdenigrescente no ápice. 11

11. Nervura principal não carenada abaxialmente; presença de pontuações glandulares não visíveis a olho nu na lâmina foliar

6. Anthurium loefgrenii

11'. Nervura principal carenada abaxialmente; ausência de pontuações glandulares na lâmina foliar .10 Anthurium sellowianum

1. Anthurium acutum N.E.Br., Gardeners' Chronicle, 3(2): 776. 1887.

Fig. 2a-c; Apêndice 1a-h

Terrestre ou rupícola; caule ereto, entrenós $0,4-1 \mathrm{~cm}$ compr. Catafilos e profilos jovens verdes ou róseos; senescentes castanhos, inteiros ou desmanchando em fibras, caducos na base do caule, 2,4-4,5 cm compr. Folhas simples; pecíolo 17,4$64,5 \mathrm{~cm}$ compr., verde, base alvo-rosada; cilíndrico a levemente achatado na face adaxial, carena ausente, sulco ausente; pontuações glandulares ausentes; genículo $0,9-2,5 \mathrm{~cm}$ compr., espessura maior ou igual à do pecíolo, verde a verde-amarelado em material fresco e verde escuro ou nigrescente em material seco, pontuações glandulares ausentes. Lâmina sagitada a hastada, 13-33,3 × 5,5-16 $\mathrm{cm}$, deflexa a patente em relação ao caule, sino rômbico, parabólico, hipocrateriforme, triangular ou espatulado, ápice acuminado, apiculado ou rostrado, base sagitada a hastada, cartácea, lustrosa, levemente discolor, verde abaxialmente, margem inteira, pontuações glandulares ausentes. Nervura principal obtusa na base, aguda no meio e ápice, carena ausente, levemente proeminente apenas 
no meio na face adaxial; obtusa, carena ausente, levemente proeminente da base para o ápice na face abaxial. Nervuras secundárias inconspícuas a impressas adaxialmente, evidentes a levemente proeminentes abaxialmente, $11-13$ pares no lobo anterior, nervuras basais 1 , nervuras acroscópicas 1, nervuras basioscópicas 2-4 por lobo posterior; 1 nervura coletora inserida na base foliar, $0,8-2,5$ $\mathrm{cm}$ afastada da margem. Pedúnculo 33,8-62,5 $\mathrm{cm}$, um pouco maior ou menor que o pecíolo, cilíndrico, carena ausente, verde, levemente amarelado ou róseo, raro amarelado na frutificação. Espata $2,8-8,5 \times 0,5-0,8 \mathrm{~cm}$, lanceolada, não revoluta, ápice rostrado, membranácea a cartácea, persistente, deflexa; margens se encontrando no pedúnculo em um ângulo geralmente obtuso ou raso, raro agudo; verde, verde-rosado ou verdeavermelhado; decorrência no pecíolo ausente, raro presente com 0,2-0,5 cm compr. Espádice 2,2-6,5 $\times 0,3-0,4 \mathrm{~cm}$, cilíndrico afilando no ápice, verde, verde-rosado ou vináceo em pré-antese, verderosado, verde-vináceo ou verde em antese, verdevináceo, verde ou vináceo em pós-antese; séssil a raro estipitado, estípite $0,1-0,3 \mathrm{~cm}$ compr., verde ou vináceo; 3-5 flores na espiral principal, 3-9 flores na espiral secundária, maturação acrópeta. Flores filetes 1,7-1,9 × 0,9-1,1 mm, anteras 0,5-0,7 × 0,8 mm; ovário 1,6-2,2 × 1-1,3 mm, placentação axial-apical, 1 óvulo por lóculo, eixo axilar do ovário com tricomas; estigma elíptico ou globoso. Espádice em frutificação 5,1-8,2 $\times$ 0,8-1,4 cm, ereto, palha, amarelado ou alaranjado, maturação das bagas acrópeta a dispersa. Bagas 4,9-6 × 4,5-5,4 mm, globosas a obovoides, verdenigrescentes ou vináceo-nigrescentes no ápice, verde-translúcidas ou vináceo-nigrescentes na base. Sementes oblongas afilando na base em vista dorsal, achatadas na face adaxial, convexas na face abaxial, amarelado-alvascentes.

Diferencia-se das demais espécies pelo hábito terrestre ou rupícola e a lâmina foliar sagitada a hastada. Floresce e frutifica o ano inteiro. No material analisado a placentação é do tipo axial apical, o que difere do encontrado por Temponi (2006) que foi do tipo axial.

É endêmica do Brasil, encontrada nos estados de Paraná, Santa Catarina e São Paulo. No Paraná foi encontrada em seis municípios em áreas de Floresta Ombrófila Densa Montana e Altomontana (Fig. 1). Nos outros estados onde ocorre é classificada como Pouco Preocupante quanto ao seu estado de conservação, e no Paraná também, pois apesar de ter extensão de ocorrência menor que $20.000 \mathrm{~km}^{2}$ e área de ocupação menor que $2.000 \mathrm{~km}^{2}$, foi encontrada em 11 localidades com um grande número de indivíduos.

Material selecionado: Guaraqueçaba, Morro Cunhaporanga, 19.XI.2003, fl., E. Barbosa 785 (MBM). Guaratuba, Usina Guaricana, 05.VII.2012, fl., A.P. Cardozo 61 (UPCB). Morretes, Pilão de Pedra, 4.XII.1959, fl., G. Hatschbach 6653 (MBM; RB). Paranaguá, Serra da Prata, 20.VI.1998, fl., J.M. Silva et al. 2406 (FLOR; MBM). Piraquara, Fazenda Céu Azul, 3.VI.1970, fl., G. Hatschbach 24390 (MBM). São José dos Pinhais, RPPN Nhandara Guaricana, 21.IV.2013, fl. e fr., L.C. Ferneda Rocha et al. 160 (UNOP; UPCB).

2. Anthurium comtum Schott, Bonplandia, 10: 87. 1862 .

Fig. 2d-h; Apêndice 2a-e

Epífita a raro rupícola; caule ereto, entrenós curtos com até $0,5 \mathrm{~cm}$ compr. Catafilos e profilos jovens verdes, base creme ou rósea; senescentes palha a castanhos, desmanchando em fibras, caduco para a base do caule a raro persistentes, 1,7-3,9 cm compr. Folhas simples; pecíolo 1,4-15,2 cm compr., verde, raro com base alva; geralmente achatado a levemente 1-2-sulcado, margens carenadas adaxialmente; carena ausente, sulco ausente, obtuso abaxialmente; pontuações glandulares ausentes; genículo 0,2-1,3 cm compr., espessura igual ou maior à do pecíolo, verde em material fresco e nigrescente em material seco, pontuações glandulares ausentes. Lâmina oblonga, linear, lanceolada, 17,8-42,8 × 2,6-9,7 cm, ereta em relação ao caule, ápice acuminado, apiculado a caudado, base geralmente obtusa, aguda a raro longo-cuneada, membranácea a raro levemente cartácea, lustrosa, discolor, verde-amarelada abaxialmente, margem inteira, pontuações glandulares ausentes. Nervura principal obtusa a aguda, carena ausente, levemente proeminente apenas no meio adaxialmente; obtusa a aguda, frequentemente carenada, proeminente da base para o ápice abaxialmente. Nervuras secundárias impressas adaxialmente, levemente proeminentes abaxialmente, 22-30 pares; 1 nervura coletora inserida na base foliar, 0,3-1 cm afastada da margem. Pedúnculo 9,2-33,5 cm compr., maior que o pecíolo, cilíndrico a 1-3 carenado, verde, raro com base rósea ou alva, amarelo na frutificação. Espata 4,3-9,3 × 0,5-0,8 cm, lanceolada, não revoluta, ápice rostrado, membranácea a cartácea, geralmente caduca em antese ou frutificação, a persistente, geralmente deflexa, raro ereta a 


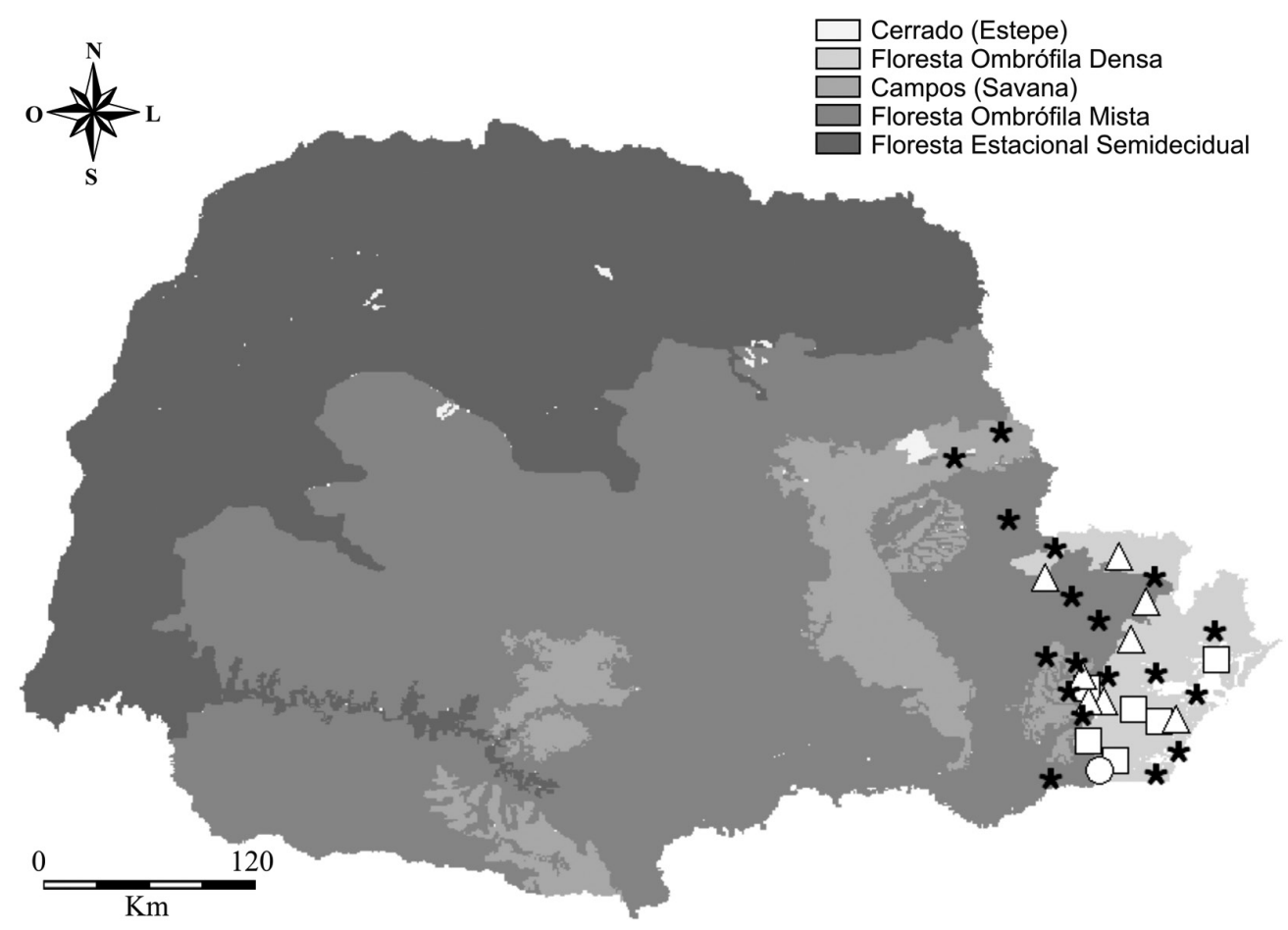

Figura 1 - Distribuição geográfica de Anthurium acutum ( $\square$ ), A. comtum $(\triangle)$, A. gaudichaudianum $(\star)$ e A. hatschbachii $(\mathrm{O})$ no estado do Paraná, Brasil.

Figure 1 - Geographic distribution of Anthurium acutum $(\square)$, A. comtum $(\triangle)$, A. gaudichaudianum ( $\star$ ) e A. hatschbachii $(\mathrm{O})$ in Paraná state, Brazil.

patente; margens se encontrando no pedúnculo em um ângulo agudo ou obtuso; verde ou verdearroxeada; decorrência no pecíolo presente, até 0,4 (1) cm compr. Espádice 4,7-10,9 × 0,2-0,5 $\mathrm{cm}$, cilíndrico a afilado no ápice, verde ou vinácea em pré-antese e antese, avermelhado em antese, cor-de-palha a pardacento em pós-antese; séssil a estipitado, estípite $0,1-0,4$ (1) $\mathrm{cm}$ compr., verde; 3-6 flores na espiral principal, 4-8 flores na espiral secundária, maturação acrópeta ou dispersa. Flores filetes $0,7-1 \times 0,5-0,7 \mathrm{~mm}$, anteras $0,3-0,5 \times 0,5-0,7$ $\mathrm{mm}$; ovário $1,1-1,7 \times 0,8-1 \mathrm{~mm}$, placentação axialapical, 1 óvulo por lóculo, eixo axilar do ovário com tricomas; estigma elíptico. Espádice em frutificação 5,7-9,4 × 0,6-1 cm, ereto, alaranjado, maturação das bagas acrópeta, homogênea ou dispersa. Bagas 2-4 $\times 2-4 \mathrm{~mm}$, globosas, verde translúcidas na base e ápice. Sementes ovoides em vista dorsal, achatadas a convexa na face adaxial; convexas na face abaxial, amarelo-alvescentes.

Diferencia-se das demais espécies pelo hábito epífito, lâmina foliar discolor, verde-amarelada abaxialmente, geralmente membranácea, espata geralmente decídua, espádice cor-de-palha a pardacento em pós-antese. Floresce e frutifica o ano inteiro.
É endêmica do Brasil, é encontrada nos estados do Sudeste, na Bahia e no Paraná. Neste último foi encontrada em oito municípios, em locais sombreados nas áreas de Floresta Ombrófila Densa Submontana e Montana (Fig. 1). Nos outros estados onde ocorre é classificada como Pouco Preocupante quanto ao seu estado de conservação, e no Paraná também, pois apesar de ter extensão de ocorrência menor que $20.000 \mathrm{~km}^{2} \mathrm{e}$ área de ocupação menor que $2.000 \mathrm{~km}^{2}$, foi encontrada em 12 localidades com um número grande de indivíduos.

Material selecionado: Adrianópolis, Parque Estadual (P.E.) das Lauráceas, 19.II.2013, fl., L.C. Ferneda Rocha 114 (UNOP;UPCB). Antonina, Cabeceira do Rio Faisqueira, 29.XI.1973, fl., G. Hatschbach 33404 (MBM). Bocaiúva do Sul, Rio Capivari, 11.XI.1968, fl. e fr., G. Hatschbach 20250 (MBM). Cerro Azul, Cabeceira do Rio do Tigre, 18.VIII.1984, fr., G. Hatschbach 48102 (MBM). Morretes, Estrada da Graciosa, 15.VI.2013, fl. e fr., M.E. Engels et al. 1611 (UNOP); Estrada da Graciosa, 30.VIII.2012, fl., M.E. Engels 505 (UNOP). Quatro Barras, Caminho do Itupava, 16.VI.2012, fr., M.E. Engels 395 (UPCB). Paranaguá, Tinguçu, 27.XII.2013, R.A. Bonaldi (MBM). Piraquara, Morro do Canal, 30.X.2009, fl., R. Kersten 1407 (HUCP). 
3. Anthurium gaudichaudianum Kunth, Numeratio Plantarum Omnium Hucusque Cognitarum, 3: 74. 1841.

Fig. 2i-n; Apêndice 3a-j

Epífita ou saxícola, ocasionalmente terrestre; caule ereto, entrenós $0,2-0,6 \mathrm{~cm}$ compr. Catafilos e profilos jovens verdes a creme; senescentes palha ou castanhos, inteiros, raro desmanchando em fibras apenas na base, persistentes, 2,7-22 cm compr. Folhas simples; pecíolo 3,5-41,5 cm compr., verde, verde com base creme, raro arroxeado; cilíndrico ou achatado, raro 1-sulcado, margem aguda a obtusa, carenas ausentes adaxialmente; carena ausente, sulco ausente, obtuso abaxialmente; pontuações glandulares ausentes; genículo 0,3-2 $\mathrm{cm}$ compr., espessura igual ou maior à do pecíolo, verde amarelado em material fresco e nigrescente ou castanho em material seco, pontuações glandulares ausentes. Lâmina lanceolada com a base mais estreitada, linear a raro oblonga, $11-65,5 \times 1,7-9,3 \mathrm{~cm}$, ereta, raro ereta em relação ao caule, ápice agudo ou acuminado, base obtusa, truncada ou aguda, raro estreito-cuneada, cartácea, lustrosa ou fosca, concolor, verde abaxialmente, margem inteira, pontuações glandulares ausentes. Nervura principal obtusa na base, aguda no meio e ápice, carena ausente, sulco ausente, proeminente na base adaxialmente; obtusa ou aguda, carena ausente, sulco ausente, bem proeminente apenas na base abaxialmente. Nervuras secundárias inconspícuas, 23-63 pares, nervura coletora inserida na base foliar ou um pouco acima dela, $0,2-1,2 \mathrm{~cm}$ afastada da margem. Pedúnculo $14,2-63,3 \mathrm{~cm}$ compr., maior que o comprimento do pecíolo, cilíndrico, carena ausente, roxo, róseo, verde, verde com ápice roxo, raro com a base creme, verde ou amarelo na frutificação. Espata 3,2-20 × 0,6-1,5 cm, oblonga ou lanceolada, não revoluta, ápice rostrado, cartácea, persistente a raro caduca, geralmente deflexa, raro patente ou ereta; margens se encontrando no pedúnculo em um ângulo agudo ou obtuso; rósea, verde, roxa ou castanha; decorrência no pecíolo presente, 0,2-1,6 cm compr. Espádice 4,1-18,5 × 0,3-0,6 $\mathrm{cm}$, cilíndrico, verde, castanho ou roxo em préantese, roxo ou verde em antese, castanho ou verde-arroxeado em pós-antese; estipitado, estípite $(0,1)-0,5-2,5$ cm compr., castanho, verde ou roxo; 4-8 flores na espiral principal, 5-8 flores na espiral secundária, maturação acrópeta ou homogênea. Flores filetes $1-1,9 \times 0,6-0,9 \mathrm{~mm}$, anteras $0,6-0,7 \times 0,8-1 \mathrm{~mm}$; ovário $1,2-1,7 \times 0,8-1 \mathrm{~mm}$, placentação axial apical, 2 óvulos por lóculo, eixo axilar do ovário com tricomas; estigma elíptico a raro globoso. Espádice em frutificação 4,8-29,5 $\times 0,7 \mathrm{~cm}$, arqueada-pendente, castanho, amarelo ou alaranjado, maturação das bagas acrópeta, homogênea ou dispersa. Bagas 4,5-5,6 × 3,4-4 $\mathrm{mm}$, obcônicas ou globosas, geralmente amarelas, raro verde translúcidas na base e alaranjadas, verdes ou cinza no ápice. Sementes oblongas achatadas lateralmente em vista dorsal, convexa em ambas as faces a reta na face adaxial, amarelo-alvascentes.

É facilmente reconhecida pelos catafilos inteiros, persistentes e geralmente longos com até $22 \mathrm{~cm}$ compr., nervação secundária inconspícua, espádice estipitado e bagas geralmente amarelas. Floresce e frutifica o ano inteiro.

É endêmica do Brasil, distribuindo-se apenas nos estados do Paraná, Santa Catarina e São Paulo. Amplamente distribuída no Paraná, ocorrendo em 18 municípios, em áreas de Cerrado, Floresta Ombrófila Densa Submontana e Montana, e transição entre Floresta Ombrófila Densa e Floresta Ombrófila Mista (Fig. 1). Nos outros estados onde ocorre é classificada como Pouco Preocupante quanto ao seu estado de conservação, e no Paraná também, pois tem extensão de ocorrência maior que $20.000 \mathrm{~km}^{2}$, área de ocupação maior que $2.000 \mathrm{~km}^{2}$ e foi encontrada em mais de 20 localidades com um grande número de indivíduos.

É semelhante a $A$. langsdorfii Schott, que é hemiepífita, possui catafilos levemente decompostos, caducos e menores que $5 \mathrm{~cm}$ compr.; enquanto $A$. gaudichaudianum tem hábito geralmente epífito, catafilos inteiros, persistentes e com até $22 \mathrm{~cm}$ compr. Também pode ser confundida com a A. longifolium (Hoffmanns.) G. Don, que possui 5-22 nervuras secundárias e bagas avermelhadas a vináceas, enquanto A. gaudichaudianum possuí 23-63 nervuras secundárias e bagas geralmente amarelas a raro esverdeadas ou alaranjadas.

Alguns espécimes encontrados na população de uma área de Cerrado, no município de Sengés, apresentam hábito saxícola ou terrestre, folhas oblongas e podem apresentar as bagas esverdeadas a alaranjadas, quando comparada às populações que são epífitas em Mata Atlântica e tem lâmina foliar lanceolada a linear, e bagas amareladas.

Material selecionado: Adrianópolis, P.E. das Lauráceas, 19.II.2003, fl., L.C. Ferneda Rocha et al. 118 (UNOP). Antonina, Reserva Natural do Morro da Mina, 13.I.2008, fl., M.P. Petean (MBM 350324). Bocaiúva do Sul, 
Cerro das Flores, 08.VII.1989, fl., V. Nicolack et al. 5 (MBM). Campina Grande do Sul, Serra da Espia, 15.VIII.1962, fl., G. Hatschbach 9232 (MBM). Cerro Azul, Rio do Turvo, 21.VII.1970, fl. e fr., G. Hatschbach 24508 (MBM). Colombo, Roseira, 26.VIII.2010, fl. e fr., M. Verdi et al. 5535 (RB). Doutor Ulysses, Serra Paranapiacaba, 12.XII.1993, fl., G. Hatschbach 59222 (MBM). Guaraqueçaba, 23.XI.2012, fl., L.C. Ferneda Rocha et al. 81 (UPCB). Guaratuba, Morro dos Perdidos, 29.VI.2013, fl., L.C. Ferneda Rocha et al. 224 (UNOP; UPCB). Jaguariaíva, estrada de ferro, 5.V.2006, fl., E. Barbosa et al. 1350 (MBM). Matinhos, P.E. Rio da Onça, 25.V.1998, fl., G. Martinelli et al. 15008 (RB). Morretes, Parque Nacional (ParNa) Saint HilaireLange, 28.XI.2012, fl. e fr., L.C. Ferneda Rocha et al. 95 (UNOP). Paranaguá, ParNa Saint Hilaire-Lange, 27.XI.2012, fl., L.C. Ferneda Rocha et al. 84 (UPCB). Piraquara, Morro do Canal, 28.VI.2013, fl., L.C. Ferneda Rocha et al. 212 (UNOP). São José dos Pinhais, RPPN Nhandara guaricana, 21.IV.2013, fl. e fr., L.C. Ferneda Rocha et al. 159 (UNOP;UPCB). Sengés, RPPN Vale do Corisco, 25.V.2012, fl., M.E. Engels 594 (UNOP). Tijucas do Sul, III.2013, fl., $V$. Daniel et al. (UNOP 1029). Tunas do Paraná, Serra da Bocaina, 10.V.2012, fl. e fr., M.E. Engels 388 (UNOP).

\section{Anthurium hatschbachii E.G.Gonç., Aroideana,} 34: 64. 2011.

Fig. 2o-r; Apêndice 4a-e

Terrestre ou epífita; caule ereto, entrenós 0,3-0,6 cm compr. Catafilos e profilos jovens esverdeados a alvo-avermelhados; senescentes castanhos, cartáceos, inteiros, persistentes, 4,5-11 cm compr. Folhas simples; pecíolo 21,8-61,6 cm compr., verde a verde com a base vermelha; achatado, 1-sulcado, margem obtusa, carena ausente adaxialmente; carena ausente, sulco ausente, arredondado abaxialmente; pontuações glandulares presentes; genículo 1-3,3 cm compr., mais espesso que o pecíolo, verde em material fresco e nigrescente em material seco, pontuações glandulares presentes. Lâmina ovada, 25,5-38,4 $\times 12-22,3 \mathrm{~cm}$, deflexa em relação ao caule, sino triangular-estreito, ápice agudo, acuminado e rostrado, base cordada, lobos basais geralmente imbricados a não imbricados em folhas jovens, cartácea, lustrosa, discolor, verde abaxialmente, margem inteira, pontuações glandulares visíveis a olho nu em ambas as faces, alvas ou esverdeadas. Nervura principal obtusa na base, arredondada no meio e ápice, mais proeminente no meio adaxialmente; arredondada, bem mais proeminente na base abaxialmente. Nervuras secundárias fortemente impressas adaxialmente, proeminentes abaxialmente, 13-19 pares no lobo anterior, nervuras basais 2 por lobo posterior, nervuras acroscópicas ausentes, nervuras basioscópicas ausentes, nervura coletora inserida na base foliar, 0,8-2,3 $\mathrm{cm}$ afastada da margem. Pedúnculo 22-48 cm compr., maior ou menor que o pecíolo, cilíndrico, verde, verde na frutificação. Espata $3,7-9,5 \times 0,8-1,5 \mathrm{~cm}$, lanceolada a oblonga, não revoluta, ápice rostrado, membranácea, persistente a caduca na frutificação, deflexa ou ereta; margens se encontrando no pedúnculo em um ângulo obtuso; verde a rosado; decorrência no pecíolo ausente. Espádice 4-10 × 0,3-0,7 cm, cilíndrico, roxo em pré-antese, vináceo a rosa em antese, verde a palha em pós-antese; séssil a raro estipitado, estípite $0,1 \mathrm{~cm}$ compr., verde a palha; 5-8 flores na espiral principal, 6-7 flores na espiral secundária, maturação acrópeta. Flores filletes $1-1,5 \times 0,4-1$ $\mathrm{mm}$, anteras $0,6-0,9 \times 0,6-0,8 \mathrm{~mm}$; ovário $0,9-1 \times$ 1,7-1,8 mm, placentação axial-apical, 2 óvulos por lóculo, eixo axilar do ovário com tricomas; estigma elíptico a globoso. Espádice em frutificação 8,1-8,5 $\times 0,8 \mathrm{~cm}$, ereto, verde ou palha, maturação das bagas acrópeta, homogênea a dispersa. Bagas imaturas verdes. Sementes não vistas.

Facilmente reconhecida pela lâmina foliar de base cordada com pontuações glandulares em ambas as faces. Encontrada com flores em julho e com flores e frutos em setembro. A. hatschbachii é muito semelhante às outras espécies de lâmina cordada: A. augustinum K.Koch \& Lauche, $A$. laucheanum K.Koch, A. lhotzkyanum Schott, $A$. lucidum Kunth, $A$. maximilianii Schott e $A$. parvum N.E.Br., diferenciando-se dessas pela presença de pontuações glandulares em ambas as faces da lâmina foliar, no genículo e no pecíolo.

A descrição original da espécie foi baseada em material de herbário e descreve a lâmina foliar como concolor com nervuras fracamente visíveis (Gonçalves 2011). A análise do material em campo permitiu observar que a lâmina foliar é discolor com nervação visível em ambas as faces da lâmina (Fig. 10b,c), o que vem complementar a descrição tipo.

A espécie é endêmica dos estados do Paraná (Fig. 1) e Santa Catarina em áreas de Floresta Ombrófila Densa Montana. Apesar de também ocorrer em Santa Catarina onde é classificada como Em Perigo, no Paraná é classificada como Criticamente em Perigo quanto ao seu estado de conservação, pois ela ocorre em apenas uma localidade com área de ocupação menor que 10 $\mathrm{km}^{2}$, foram encontrados apenas dois indivíduos e esta área não é de preservação ambiental. 


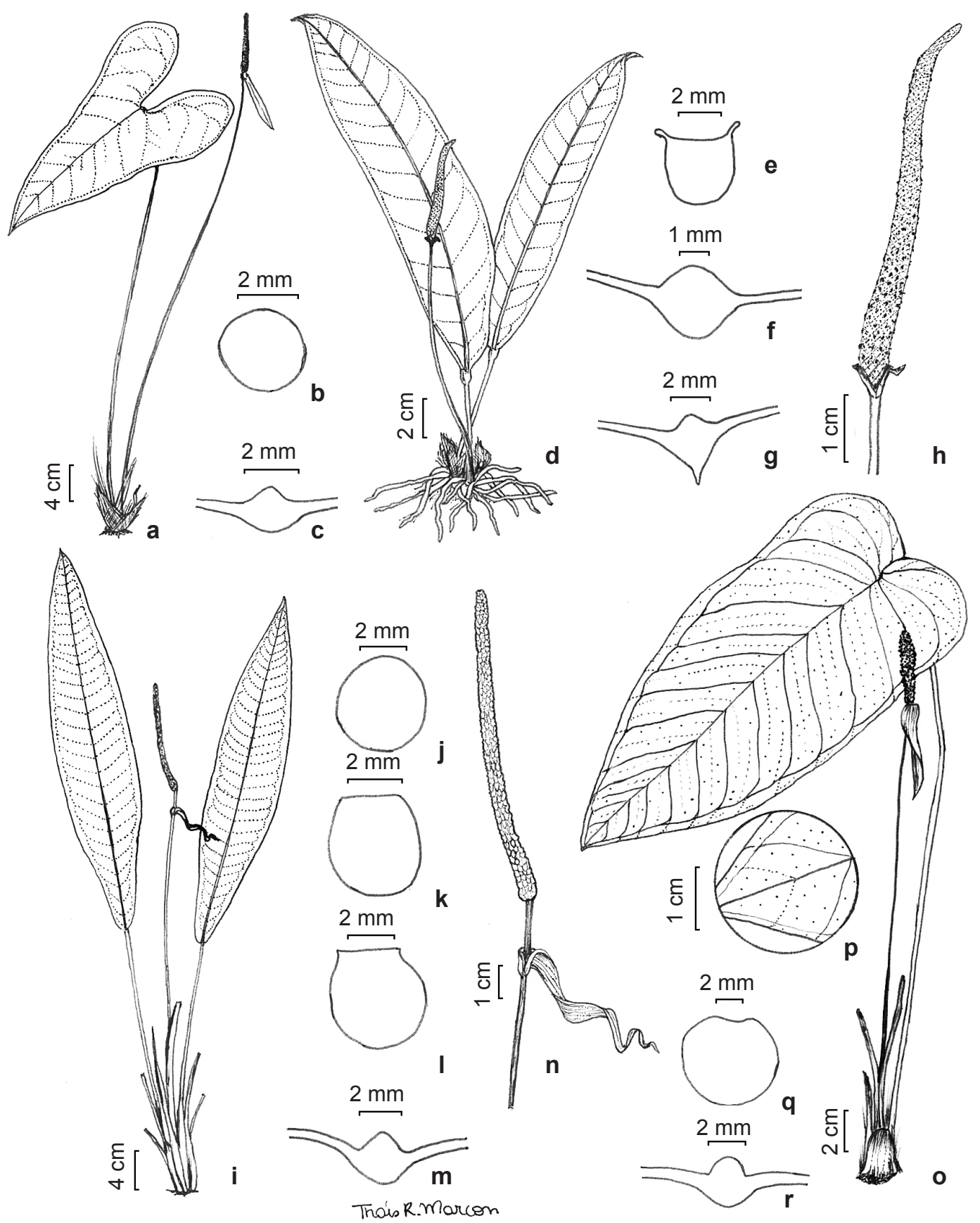

Figura 2 - a-c. Anthurium acutum - a. hábito; b. pecíolo em corte transversal; c. nervura principal em corte transversal (L.C. Ferneda Rocha 160). d-h. Anthurium comtum - d. hábito; e. pecíolo em corte transversal; f-g. nervura principal em corte transversal; h. espádice (L.C. Ferneda Rocha 274). i-n. Anthurium gaudichaudianum - i. hábito; j-1. pecíolo em corte transversal; m. nervura principal em corte transversal; n. espádice (L.C. Ferneda Rocha 56). o-r. Anthurium hatschbachii - o. hábito; p. detalhe da lâmina foliar com pontuações glandulares; q. pecíolo em corte transversal; r. nervura principal em corte transversal (A. P. Cardozo 63).

Figure 2 - a-c. Anthurium acutum - a. habit; b. transversal section of petiole; c. transversal section of midrib (L.C. Ferneda Rocha 160). d-h. Anthurium comtum - d. habit; e. transversal section of petiole; f-g. transversal section of midrib; h. spadix (L.C. Ferneda Rocha 274). i-n. Anthurium gaudichaudianum - i. habit; j-1. transversal section of petiole; m. transversal section of midrib; n. spadix (L.C. Ferneda Rocha 56). o-r. Anthurium hatschbachii - o. habit; p. detail blade with glandular punctuations; q. transversal section of petiole; r. transversal section of midrib (A. P. Cardozo 63). 
Material examinado e adicional: PARANÁ, Guaratuba, Rio Itararé, XII.1962, fl., G. Hatschbach 9689 (holótipo MBM); Serra de Araçatuba, 22.XII.1959, fl., G. Hatschbach 6644 (MBM; RB). SANTA CATARINA, Joinville, 07.VII.2012, fl., A.P. Cardozo 63 (UPCB); 07.VII.2012, fl. e fr., A.P. Cardozo 62 (UPCB).

5. Anthurium lacerdae Reitz, Sellowia - Anais Botânicos do HBR, 8: 59-61. 1957.

Fig 3a-f; Apêndice 5a-e

Epífita, rupícola ou terrestre; caule ereto, entrenós $0,5-0,9 \mathrm{~cm}$ compr. Catafilos e profilos jovens verde-claro a cremes; senescentes palha, desmanchando em fibras, decíduos para a base do caule, 7,8-12 cm compr. Folhas simples; pecíolo 27,8-43,3 cm compr., verde; cilíndrico, carena ausente, sulco ausente; pontuações glandulares ausentes; geniculo 1,5-1,8 cm compr., mesma espessura do pecíolo, verde mais claro que o pecíolo em material fresco e castanho ou verde em material seco, pontuações glandulares ausentes. Lâmina elíptica ou oblonga, 41-80,3 $\times 8-31 \mathrm{~cm}$, ereta em relação ao caule, ápice agudo, base estreito-cuneada, coriácea, fosca, concolor, verde abaxialmente, margem inteira, pontuações glandulares ausentes. Nervura principal achatada, carena ausente, levemente proeminente adaxialmente; obtusa, carena ausente, proeminente abaxialmente. Nervuras secundárias inconspícuas, 30-45 pares; 2 nervuras coletoras, uma inserida um pouco acima da base foliar e $0,8-3 \mathrm{~cm}$ afastada da margem, a outra inserida na base foliar e até 0,4 $\mathrm{cm}$ afastada da margem. Pedúnculo 6-19,6 cm compr., com menos da metade do comprimento do pecíolo, cilíndrico, carena ausente, verde, verde na frutificação. Espata 9,2-18,8 × 1,3-3,9 $\mathrm{cm}$, oblonga, revoluta, ápice rostrado, coriácea, persistente, geralmente ereta a raro patente; margens se encontrando no pedúnculo em um ângulo obtuso a raso, com o centro agudo-curto; roxa adaxialmente em pré-antese e antese, verde, verde-vinácea ou cor-de-palha a pardacento adaxialmente em pós-antese, verde abaxialmente; decorrência no pecíolo presente, $0,6-1,4 \mathrm{~cm}$ compr. Espádice 9-18,7 × 0,7-1,6 cm, cilíndrico, vináceo em pré-antese, palha em antese e pós-antese; séssil a raro estipitado, estípite $0,3-0,35 \mathrm{~cm}$ compr.; $6-15$ flores na espiral principal, 10-19 flores na espiral secundária, maturação acrópeta a dispersa. Flores filetes $0,5-2,2 \times 1-1,9 \mathrm{~mm}$, anteras $0,7-1 \times 0,9-1,1$ $\mathrm{mm}$; ovário 2,7-3,4 × 1,7-2,2 mm, placentação axial, 1 óvulos por lóculo, eixo axilar do ovário com tricomas; estigma elíptico a globoso. Espádice em frutificação $11-16,8 \times 1,6-2,3 \mathrm{~cm}$, ereto, palha a castanho, maturação das bagas acrópeta, homogênea a dispersa. Bagas 8,4-9,6 × 4,1-5 mm, oblongas a suboblongas, alvas ou alvo-translúcidas na base e verdes no ápice. Sementes oblongas, achatadas lateralmente, convexas na face adaxial, convexas a retas na face adaxial, amarelas.

Pode ser reconhecido pela lâmina foliar e espata coriáceas, pedúnculo com menos da metade do comprimento da lâmina foliar, espata vinácea adaxialmente e verde abaxialmente em pré-antese e antese. Floresce o ano inteiro, encontrada com frutos em novembro.

É endêmica do Brasil e até então era conhecida apenas para o Paraná e Santa Catarina, porém durante as visitas aos herbários foram encontrados registros para os estados do Espírito Santo, São Paulo e Rio de Janeiro. No Paraná foi encontrada em quatro municípios, em áreas de Floresta Ombrófila Densa de Terras Baixas e Submontana (Fig. 4). Embora ocorra em outros estados onde é classificada como Pouco Preocupante, no Paraná se enquadra na categoria Vulnerável quanto ao seu estado de conservação, pois tem extensão de ocorrência menor que 20.000 $\mathrm{km}^{2}$, área de ocupação menor que $2.000 \mathrm{~km}^{2}$, foi encontrada em seis localidades com um número pequeno de indivíduos.

Anthurium lacerdae é muito semelhante a Anthurium coriaceum G. Don, tanto que as duas espécies foram consideradas sinônimas nos trabalhos de Berkenbock (2005) e Temponi (2006). Neste estudo tratamos as duas espécies como distintas, pois apresentam tamanho do pedúnculo e cor da espata diferentes, como apontada por Reitz (1957).

Nos exemplares analisados a espata é vinácea adaxialmente em pré-antese e antese, e o pedúnculo tem no máximo metade do comprimento do pecíolo como apontado para Anthurium lacerdae por Reitz (1957). Entretanto, ao avaliar outros caracteres como a largura e o formato de espádice, além da distribuição geográfica, os exemplares analisados se confundem com Anthurium coriaceum, sugerindo que essas duas espécies precisam ser melhor estudadas para defini-las como espécies autônomas. Material selecionado: Guaraqueçaba, 23.XI.2012, fl., L.C. Ferneda Rocha et al. 78 (UNOP). Guaratuba, Rio São João, 3.VIII.1962, fl., G. Hatschbach 9215 (MBM). Morretes, Rio Bromado, 13.IX.1979, fl., G. Hatschbach 42505 (MBM). Paranaguá, Ilha dos Currais, 15.IX.1973, fl., G. Hatschbach 32538 (MBM). 

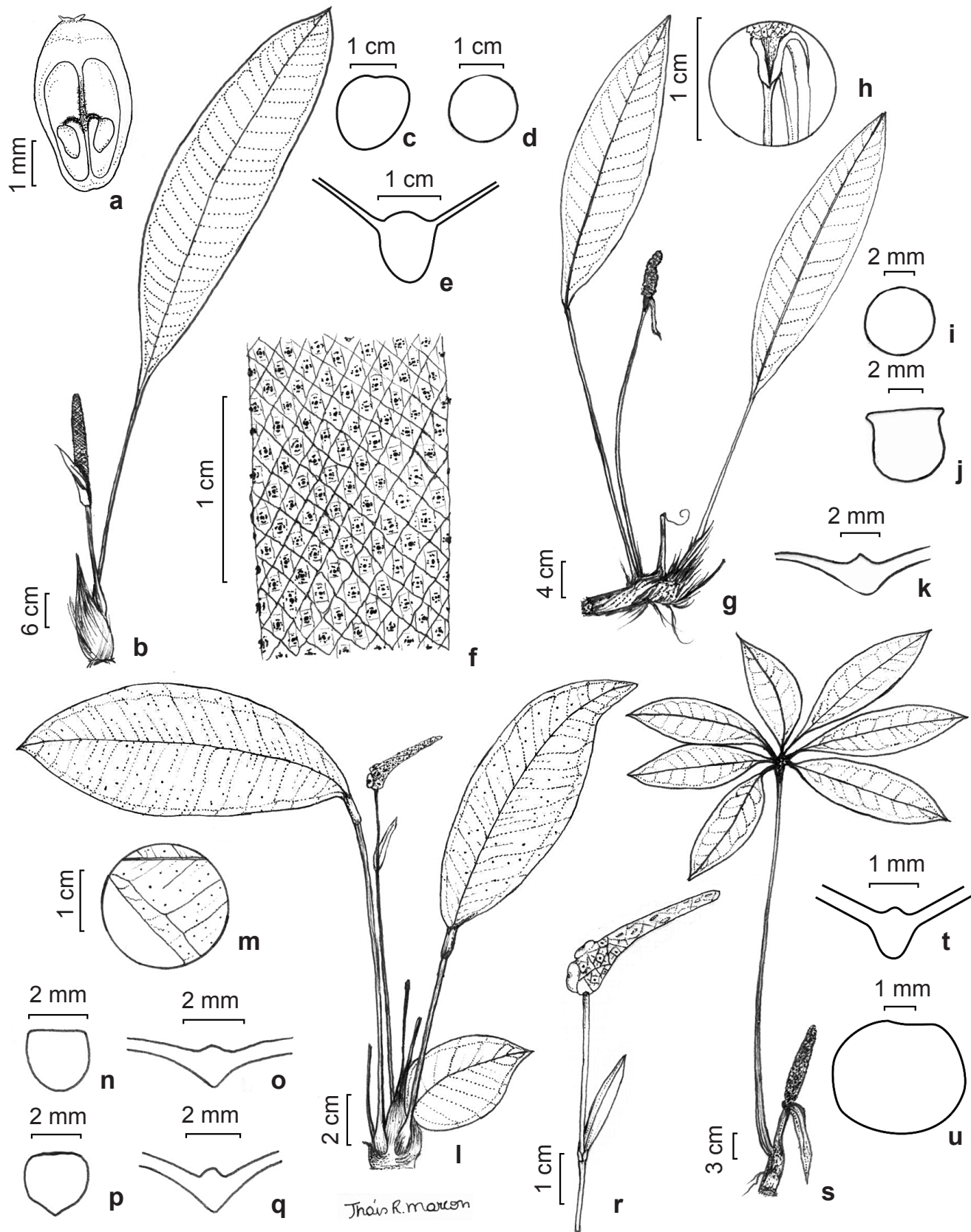

Figura 3 - a-f. Anthurium lacerdae - a. placentação axial; b. hábito; c-d. pecíolo em corte transversal; e. nervura principal em corte transversal; f. espádice mostrando numerosas flores nas espirais (L.C. Ferneda Rocha 79). g-k. Anthurium loefgrenii - g. hábito; $\mathrm{h}$. decorrência da espata curta; i-j. pecíolo em corte transversal; k. nervura principal em corte transversal (L.C. Ferneda Rocha 106). 1-r. Anthurium marense - 1. hábito; m. detalhe da lâmina foliar com pontuações glandulares; n-p. pecíolo em corte transversal; o-q. nervura principal em corte transversal; r. espádice (L.C. Ferneda Rocha 114). s-u. Anthurium pentaphyllum - s. hábito; t. nervura principal em corte transversal; u. pecíolo em corte transversal (A.P. Cardozo 238).

Figure 3 - a-f. Anthurium lacerdae - a. axial placentation; b. habit; c-d. transversal section of petiole; e. transversal section of midrib; f. spadix showing numerous flowers at spirals (L.C. Ferneda Rocha 79). g-k. Anthurium loefgrenii-g. habit; h. spathe short decurrent; i-j. transversal section of petiole; k. transversal section of midrib (L.C. Ferneda Rocha 106). 1-r. Anthurium marense - 1. habit; m. detail blade with glandular punctuations; n-p. transversal section of petiole; o-q. transversal section of midrib; r. spadix (L.C. Ferneda Rocha 114). s-u. Anthurium pentaphyllum - s. habit; t. transversal section of midrib; u. transversal section of petiole (A.P. Cardozo 238). 
6. Anthurium loefgrenii Engl., Das Pflanzenreich, 4(23b): 165. 1905.

Fig. 3g-k; Apêndice 6a-g

Terrestre, saxícola, ocasionalmente escandente; caule geralmente reptante a raro ereto, entrenós longos 0,3-2,2 cm compr. Catafilos e profilos jovens verdes a raro verde-arroxeados; senescentes palha ou castanhos, desmanchando em fibras, decíduo para a base do caule, 1,6-8,8 cm compr. Folhas simples; pecíolo 3,2-37,7 cm compr., verde, raro verde-avermelhado; cilíndrico ou achatado, raro 1-sulcado, margem obtusa a aguda adaxialmente; obtuso, carena ausente, raro 1-sulcado lateralmente abaxialmente; pontuações glandulares ausentes; genículo 0,4-2,2 cm compr., espessura igual ou maior à do pecíolo, verde-amarelado, verde-rosado ou verde em material fresco e verde-escuro a nigrescente em material seco, pontuações glandulares ausentes. Lâmina elíptica a lanceolada, 7-42,2 × 2,2-16,5 $\mathrm{cm}$, ereta a patente em relação ao caule, ápice agudo, obtuso, frequentemente apiculado, raro acuminado, base estreito-cuneada, longo-cuneada ou obtusa, frequentemente curtamente-atenuada na extremidade, geralmente membranácea a cartácea, lustrosa, discolor, verde abaxialmente, margem inteira, pontuações glandulares não visíveis a olho $\mathrm{nu}$, verdes. Nervura principal obtusa na base, aguda no meio e ápice, carena ausente, proeminente apenas no meio adaxialmente; geralmente obtusa, raro aguda, bem proeminente na base abaxialmente. Nervuras secundárias impressas adaxialmente, evidentes a levemente proeminentes abaxialmente, 7-18 pares, nervura coletora inserida na base foliar, raro um pouco acima dela, $0,3-2 \mathrm{~cm}$ afastada da margem. Pedúnculo 3,8-73 cm compr., um pouco maior ou menor que o pecíolo, cilíndrico, raro 1-carenado, roxo, róseo ou verde, raro esverdeadoamarelado, base rósea ou roxa, verde em frutificação. Espata 1,4-13,7 × 0,3-2 cm, lanceolada, não revoluta, ápice rostrado, membranácea, persistente a raro decídua na frutificação, geralmente deflexa, raro patente ou ereta; margens se encontrando no pedúnculo em ângulo agudo; roxa, verde, rósea; decorrência no pecíolo presente, $0,2-1,9 \mathrm{~cm}$ compr. Espádice 1,9-12,5 × 0,3-0,9 cm, cilíndrico, roxo a verde em pré-antese, roxo, vináceo, avermelhado ou verde em antese, castanho, verde ou verdeamarelado, vináceo em pós-antese; séssil a raro estipitado, estípite $0,1-0,3 \mathrm{~cm}$ compr., verde, esverdeado-vináceo, verde-avermelhado; 3-6 flores na espiral principal, 5-9 flores na espiral secundária, maturação acrópeta. Flores filetes $1-1,7 \times 0,5-0,7$ $\mathrm{mm}$, anteras $0,5-0,7 \times 0,7-1 \mathrm{~mm}$; ovário $1,4-1,8 \times$ $1,2-1,8 \mathrm{~mm}$, placentação axial-apical, 1 óvulo por lóculo, eixo axilar do ovário com tricomas; estigma elíptico. Espádice em frutificação 3,5-12,4 × 0,6-1 $\mathrm{cm}$, arqueado-pendente ou ereto, castanho ou verdeescuro, maturação das bagas acrópeta, homogênea ou dispersa. Bagas 4-4,5 × 4-4,5 mm, globosas ou obcônicas, as vezes achatadas lateralmente pelas tépalas ficando levemente quadrangulares, alvas na base, verdes a verde-nigrescentes no ápice. Sementes oblongas a disformes, achatadas na face adaxial, arredondadas na face abaxial, roxas.

Pode ser reconhecida por apresentar: hábito geralmente terrestre ou, menos frequentemente, saxícola, caule reptante ou ereto com entrenós longos e lâmina foliar elíptica a lanceolada. Ocasionalmente encontrada como epífita. Floresce e frutifica $o$ ano inteiro.

É endêmica do Brasil, encontrada nos estados do Paraná, Santa Catarina e São Paulo. No Paraná ocorre em oito municípios, em áreas de Restinga arbórea, Floresta Ombrófila Densa Aluvial e Montana (Fig. 4). Nos outros estados onde ocorre é classificada como Pouco Preocupante quanto ao seu estado de conservação, e no Paraná também, pois tem extensão de ocorrência maior que 20.000 $\mathrm{km}^{2}$, área de ocupação maior que $2.000 \mathrm{~km}^{2} \mathrm{e}$ foi encontrada em mais de 20 localidades com um número grande de indivíduos.

Anthurium itanhaense Engl. foi considerada sinônima de A. loefgrenii por Coelho \& Mayo (2007), entretanto na publicação não foram apresentados comentários sobre essa sinonimização. Atualmente, na Lista de Espécies da Flora do Brasil as duas espécies são consideradas válidas (Coelho \& Temponi 2013). Na obra tipo dessas duas espécies os únicos caracteres distintivos são a proporção entre o comprimento do pecíolo e lâmina foliar, e do pedúnculo e pecíolo. $\operatorname{Em} A$. itanhaense o pecíolo é maior do que metade do comprimento da lâmina foliar e o pedúnculo supera o pecíolo, já em $A$. loefgrenii o pecíolo é 4 a 5 vezes menor que a lâmina foliar e o pedúnculo é quase 2 vezes mais longo que o pecíolo. Entretanto, nos exemplares analisados foi observado um gradiente de variação tanto nas proporções do comprimento do pecíolo com a lâmina foliar quanto do pecíolo com o pedúnculo. Desta forma entendemos que se trata de uma única espécie, assim como apontado por Coelho \& Mayo (2007), sendo indicada sua atualização na Lista de Espécies da Flora do Brasil. 
Material examinado: Antonina, Reserva da Cachoeira, 9.XII.2012, fl. e fr., L.G. Temponi 913 (UNOP). Guaraqueçaba, ParNa de Superagui, 11.II.2013, fl. e fr., L.C. Ferneda Rocha et al.106 (UNOP;UPCB). Guaratuba, Pedra Branca do Araraquara, 15.VIII.2012, fl., M.E. Engels 489 (UNOP). Matinhos, P.E. Rio da Onça, 25.IV.12, fr., M.E. Engels 384 (UNOP). Morretes, Serra da Graciosa, 31.VIII.2012, fl., M.E. Engels 509 (UNOP). Paranaguá, BR 407, 05.VII.2013, fl., L.C. Ferneda Rocha et al. 240 (UNOP;). Pontal do Paraná, Sambaqui do Guaraguaçu, 2.X.2007, fl., A.C. Cervi et al. 9059 (MBM). Quatro Barras, Caminho do Itupava, 16.VI.2012, fl., M.E. Engels 393 (UNOP).

\section{Anthurium marense K.Krause, Notizblatt des} Botanischen Gartens und Museums zu BerlinDahlem, 9: 271. 1925.

Fig. 31-r; Apêndice 7a-f

Terrestre ou rupícola; caule ereto, entrenós 0,2-1 cm compr. Catafilos e profilos jovens alvo-rosados a verdes; senescentes castanhos, inteiros a raro desmanchando em fibras apenas na base, decíduos a persistentes para a base do caule, 1,6-3,7 cm compr. Folhas simples; pecíolo 8,5-26,9 cm compr., verde, base alvo-rosado; achatado, sulco ausente, margem aguda a carenada adaxialmente; obtuso, raro 1-carenado, sulco ausente abaxialmente; pontuações glandulares presentes; genículo 0,6-1 cm compr., espessura maior que à do pecíolo, verde mais claro que o pecíolo em material fresco e verde escuro em material seco, pontuações glandulares presentes. Lâmina elíptica a oblonga, 6,3-21 × 2,9-8,8 cm, ereta a patente em relação ao caule, ápice agudo a obtuso, raro curtamente apiculado, base geralmente obtusa, truncada ou arredondada, raro aguda, cartácea, lustrosa, discolor, verde abaxialmente, margem inteira, pontuações glandulares visíveis a olho nu, verdes. Nervura principal obtusa a aguda, carena ausente, proeminência ausente na face adaxial; aguda a 1-carenada, bem proeminente na base abaxialmente. Nervuras secundárias impressas adaxialmente, evidentes a levemente proeminentes abaxialmente, 9-14 pares, nervura coletora inserida na base foliar ou um pouco acima dela, 0,8-1,1 cm afastada da margem. Pedúnculo 11,7-46 cm compr., um pouco maior ou menor que o pecíolo, cilíndrico, 2-carenado, verde, amarelo-avermelhado, róseo a vináceo, verde na

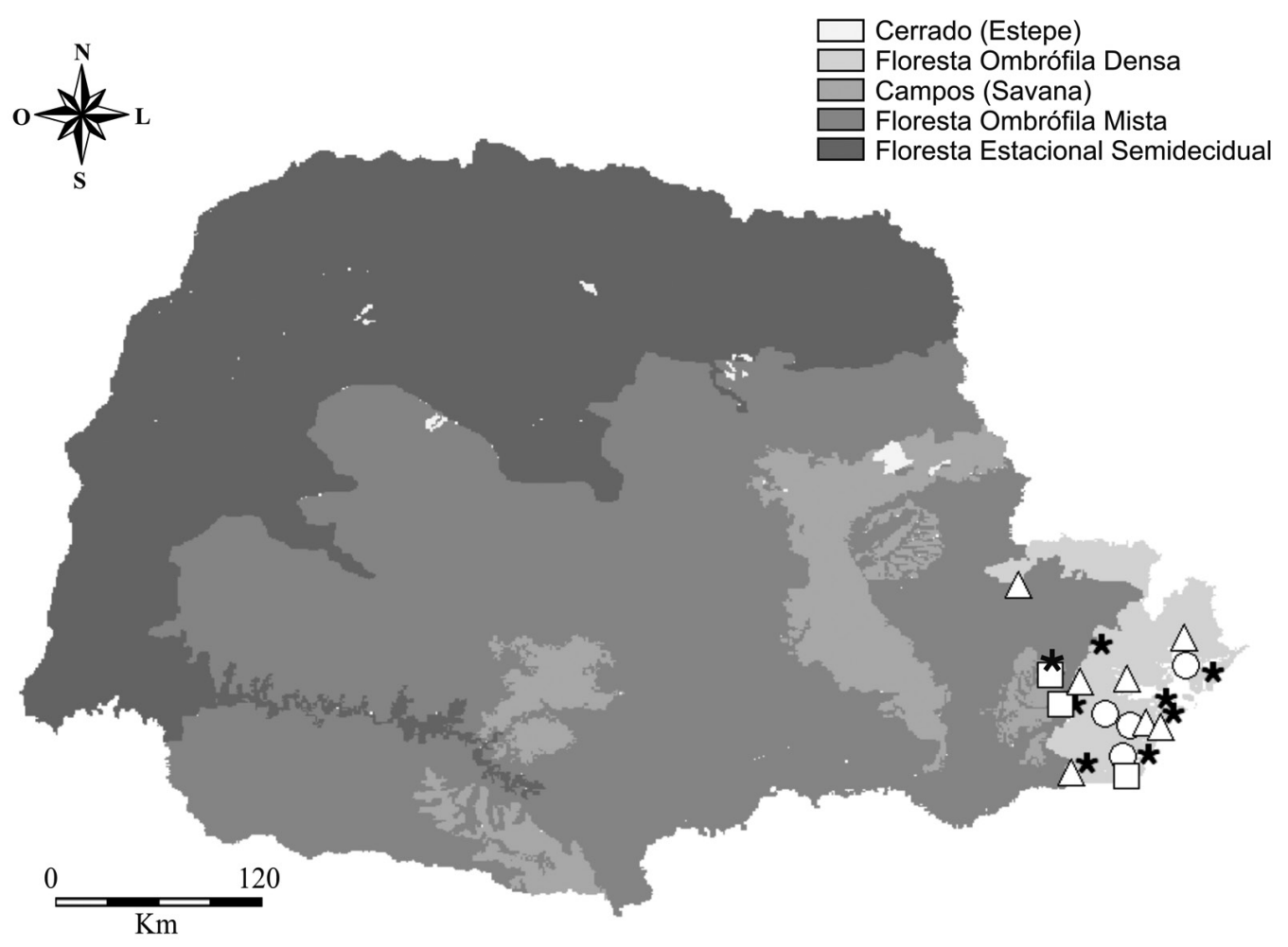

Figura 4-Distribuição geográfica de A. lacerdae $(\bigcirc)$, A. loefgrenii $(\star)$, A. marense $(\square)$ e A. pentaphyllum $(\triangle)$ no estado do Paraná. Figure 4 - Geographic distribution of A. lacerdae $(\bigcirc)$, A. loefgrenii $(*)$, A. marense $(\square)$ e A. pentaphyllum $(\triangle)$ in Paraná state, Brazil. 
frutificação. Espata $1-5,7 \times 0,2-0,8 \mathrm{~cm}$, oblonga e navicular, não revoluta, ápice rostrado, cartácea, persistente, ereta; margens se encontrando no pedúnculo em um ângulo agudo; verde, amareloavermelhada ou verde-rosada; decorrência no pecíolo ausente. Espádice 0,7-7 × 0,3-0,4 cm, cilíndrico, afilando no ápice, esverdeada ou rosa em pré-antese, creme-esverdeada ou verderosado em antese, verde-amarelado ou palha em pós-antese; estipitado, estípite 1-5,7 cm compr., verde, amarelo-avermelhado a rosado na base; $2-3$ flores na espiral principal, 3-6 flores na espiral secundária, maturação acrópeta. Flores filetes $0,6-0,9 \times 0,3-0,9 \mathrm{~mm}$, anteras $0,4-0,5 \times 0,7-0,9$ $\mathrm{mm}$; ovário $0,5-1,5 \times 0,6-1 \mathrm{~mm}$, placentação axial, 1 óvulo por lóculo, eixo axilar do ovário com tricomas; estigma geralmente globoso a raro elíptico. Espádice em frutificação 4,8-8,4 × 0,8-0,9 $\mathrm{cm}$, ereto, palha, maturação das bagas acrópeta. Bagas verdes. Sementes não analisadas.

Pode ser reconhecida pelo hábito terrestre ou rupícola, a lâmina foliar com pontuações glandulares visíveis, espata navicular e espádice longo estipitada. Pode ser confundida $\operatorname{com} A$. hoehnei $\mathrm{K}$. Krause, mas este possui base foliar com presença de sino e bagas vináceas, enquanto A. marense possuí base foliar geralmente obtusa, truncada ou arredondada e bagas verdes. Floresce e frutifica o ano inteiro.

É endêmica do Brasil onde ocorre em Minas Gerais, Paraná, Rio de Janeiro e São Paulo. No Paraná ocorre apenas em três municípios, em áreas de Floresta Ombrófila Densa Montana e Altomontana (Fig. 4). Embora tenha ampla distribuição no Brasil onde é classificada como Pouco Preocupante quanto ao seu estado de conservação, no Paraná é classificada como Vulnerável, pois tem extensão de ocorrência menor que $5.000 \mathrm{~km}^{2}$ e a área de ocupação menor que $500 \mathrm{~km}^{2}$, foi encontrado em 7 localidades, com um número grande de indivíduos.

Material selecionado: Guaratuba, Morro dos Perdidos, 29.VI.2013, fl., L.C. Ferneda Rocha et al. 219 (UNOP). Piraquara, Morro do Canal, 28.VI.2013, fl., L.C. Ferneda Rocha et al. 213 (UNOP). Quatro Barras, Trilha morros Mãe Catira e Sete, 3.VIII.2013, fl., M.E. Engels et al. 1444 (MBM).

8. Anthurium pentaphyllum (Aubl.) G. Don, Sweet's Hortus Britannicus, 3: 633. 1839.

Fig. 3s-u; Apêndice 8a-g

Hemiepífita ou epífita, ocasionalmente rupícola ou terrestre; caule escandente, entrenós 0,4
$10,7 \mathrm{~cm}$ compr. Catafilos e profilos jovens verdes; senescentes palha ou castanhos, desmanchando em fibras, decíduos para a base do caule, 2,4-11 cm compr. Folhas compostas; pecíolo 21,4-65,5 cm compr., verdes; cilíndrico a raro levemente achatado a 1-sulcado, carena ausente adaxialmente; pontuações glandulares ausentes; genículo 0,5-2 cm compr., espessura maior ou igual à do pecíolo, verde em material fresco, verde em material seco, pontuações glandulares ausentes. Lâmina palmatissecta, patente a ereta em relação ao caule, 5-11 folíolos, peciólulos subsésseis a 5,2 cm compr., folíolos 12,6-31,0 × 3,5-9,7 cm, elípticos a lanceolares, ápice acuminado a apiculado, base estreitocuneada a longo-cuneada, oblíqua, membranácea, lustrosa, discolor, verde abaxialmente, margem inteira, pontuações glandulares ausentes. Nervura principal reta, obtusa ou aguda, carena ausente, pouco proeminente adaxialmente; obtusa ou aguda, raro carenada, proeminente abaxialmente. Nervuras secundárias impressas adaxialmente, proeminentes abaxialmente, 9-18 pares, nervura coletora inserida na base do folíolo ou um pouco acima dela, 0,4-2,2 $\mathrm{cm}$ afastada da margem. Pedúnculo 1,8-18,4 cm compr., menos da metade do comprimento do pecíolo, cilíndrico, carena ausente, verde ou verdearroxeado, verde na frutificação. Espata 3,2-10,8 $\times 0,7-3,2 \mathrm{~cm}$, lanceolada ou oblonga, revoluta ou cuculada, ápice rostrado, cartácea, persistente, raro caduca em frutificação, ereta em antese e deflexa em pós-antese; margens se encontrando no pedúnculo em um ângulo obtuso ou raso, podendo ter o centro agudo; verde ou verde-arroxeada; decorrência no pecíolo ausente, raro presente com até 2,0 cm compr. Espádice 3,4-13,2 × 0,7-2 cm, geralmente cônico, raro cilíndrico, verde em préantese, roxo-acinzentado em antese e pós-antese; estípite ausente; 6-10 flores na espiral principal, 7-12 flores na espiral secundária, sequência de maturação acrópeta. Flores filetes $0,3-1,5 \times 0,8-1,2$ $\mathrm{mm}$, anteras $0,8-0,9 \times 0,9-1 \mathrm{~mm}$; ovário 1,2-2,3 $\times$ 0,7-1,7 mm, placentação axial-apical, 1 óvulo por lóculo, eixo axilar do ovário com tricomas; estigma elíptico a globoso. Espádice em frutificação $3,5-12,9 \times 1,3-2,2 \mathrm{~cm}$, ereto, verde, roxo ou palha a castanho, maturação das bagas acrópeta, homogênea ou dispersa. Bagas 4-9,5 × 5-7,5 mm, globosas, as vezes achatadas lateralmente pelas tépalas ficando levemente quadrangulares, geralmente roxas e raro vermelhas ou alvas na base, geralmente roxas a raro róseas ou nigrescentes no ápice. Sementes oblongas a elípticas, achatadas a arredondadas na face adaxial, arredondadas na face abaxial, rósea ou amarelo-alvascentes. 


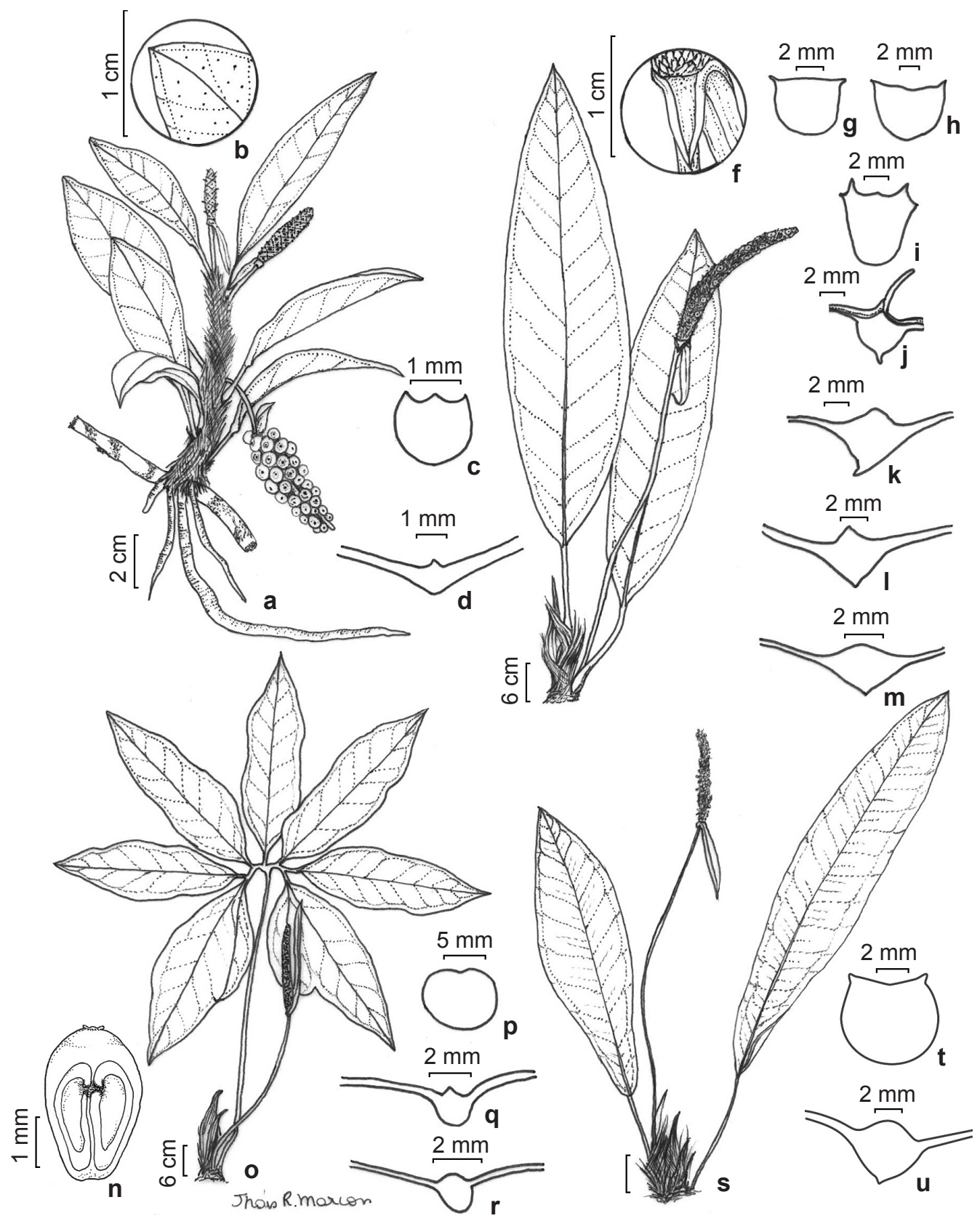

Figura 5 - a-d. Anthurium scandens subsp. scandens - a. hábito; b. detalhe da lâmina foliar com pontuações glandulares; c. pecíolo em corte transversal; d. nervura principal em corte transversal (L.C. Ferneda Rocha 119). e-m. Anthurium sellowianum - e. hábito; f. decorrência da espata longa; g-i. pecíolo em corte transversal; j-m. nervura principal em corte transversal (e.f.l. M.E. Engels 1404; ). n-r. Anthurium sinuatum - n. placentação axial apical; o. hábito; p. pecíolo em corte transversal; q-r. nervura principal em corte transversal (L.C. Ferneda Rocha 265). s-u. Anthurium urvilleanum - s. hábito; t. pecíolo em corte transversal; u. nervura principal em corte transversal (L.C. Ferneda Rocha 158).

Figure 5 - a-d. Anthurium scandens subsp. scandens - a. habit; b. detail blade with glandular punctuations; c. transversal section of petiole; d. transversal section of midrib (L.C. Ferneda Rocha 119). e-m. Anthurium sellowianum - e. habit; f. spathe long decurrent; g-i. transversal section of petiole; j-m. transversal section of midrib (M.E. Engels 1404). n-r. Anthurium sinuatum - n. apical axial placentation; o. habit; p. transversal section of petiole; q-r. transversal section of midrib (L.C. Ferneda Rocha 265). s-u. Anthurium urvilleanum - s. habit; t. transversal section of petiole; u. transversal section of midrib (L.C. Ferneda Rocha 158). 
Pode ser reconhecida pelo hábito hemiepífito, catafilos e profilos desmanchando em fibras, folha composta com folíolos de margem inteira e o pedúnculo com menos da metade do comprimento do pecíolo. Floresce e frutifica o ano inteiro.

Ocorre na costa Atlântica, desde Trinidade até o Brasil, onde ocorre nos estados da região Sudeste, e também no Acre, Amazonas, Bahia, Mato Grosso, Paraíba, Paraná, Pernambuco e Santa Catarina. No Paraná ocorre em sete municípios, em áreas de Restinga arbórea e Floresta Ombrófila Densa de Terras Baixas e Submontana (Fig. 4). Devido a sua ampla distribuição é classificada como Pouco Preocupante quanto ao seu estado de conservação, no estado do Paraná também, pois tem extensão de ocorrência maior que $20.000 \mathrm{~km}^{2}$, área de ocupação maior que $2.000 \mathrm{~km}^{2}$ e foi encontrado em 20 localidades tendo um número grande de indivíduos.

Aespécie é semelhante a $A$. brevipedunculatum Madison, entretanto este apresenta espata totalmente púrpura, ereta em frutificação e bagas com ápice rostrado, contra espata verde a verde-arroxeada, reflexa em frutificação e bagas globosas em $A$. pentaphyllum.

$A$. pentaphyllum possuí três variedades: $A$. pentaphyllum var. pentaphyllum que possuí espata persistente em frutificação, A. pentaphyllum var. bombacifolium (Jacq.) Madison e A. pentaphyllum var. digitatum (Jacq.) Madison que possuem espata decídua após a antese (Madison 1978). Alguns exemplares apresentaram espata decídua e persistente em frutificação no mesmo indivíduo, demostrando que esse caráter não é muito consistente. Deste modo o táxon será tratado apenas como A. pentaphyllum.

Material selecionado: Antonina, 03.I.1976, fl. e fr., G. Hatschbach 37939 (MBM). Cerro Azul, 8.VIII.1966, fr., J. Lindeman et al. 2120 (MBM). Guaraqueçaba, 23.XI.2012, fl. e fr., L.C. Ferneda Rocha et al. 80 (UNOP;UPCB). Guaratuba, Morro Morretes, 15.II.1964, fl., G. Hatschbach 10973 (MBM). Morretes, ParNa Saint Hilaire-Lange, 28.XI.2012, fl. e fr., L.C. Ferneda Rocha et al. 91 (UPCB). Paranaguá, BR 407, 05.VII.2013, fl. e fr., L.C. Ferneda Rocha et al. 238 (UNOP;UPCB). Pontal do Paraná, Sambaqui, 15.II.2012, fl., J.M. Silva et al. 8181 (MBM).

9. Anthurium scandens (Aubl.) Engl. subsp. scandens, Flora Brasiliensis, 3(2): 78.1878.

Fig. 5a-d; Apêndice 9a-g

Epífita; caule escandente, entrenós 0,4-1,9 cm compr. Catafilos e profilos jovens verdes a creme; senescentes palha ou castanhos, desmanchando em fibras, geralmente persistentes, raro decíduos para a base do caule, 2,4-8,5 $\mathrm{cm}$ compr. Folhas simples; pecíolo 0,6-8,5 cm compr., verde, achatado, 1-2-sulcado, margem aguda ou carenada adaxialmente; obtuso, carenas ausentes, sulcos ausentes abaxialmente; pontuações glandulares presentes; geniculo $0,2-0,8 \mathrm{~cm}$ compr., mais espesso que o pecíolo, verde-amarelado em material fresco e nigrescente em material seco, pontuações glandulares presentes. Lâmina elíptica a lanceolada, $3,2-15,3 \times 1,1-5,2 \mathrm{~cm}$, geralmente ereta a patente em relação ao caule, ápice agudo ou acuminado, base aguda, estreito-cuneada ou longo-cuneada, levemente cartácea, lustrosa ou fosca, discolor, verde abaxialmente, margem inteira, pontuações glandulares visíveis a olho nu, verdes ou negras. Nervura principal aguda, carena ausente, pouco proeminente adaxialmente; obtusa, carena ausente, proeminente da base para o ápice abaxialmente. Nervuras secundárias evidentes, 8-13 pares, nervura coletora inserida na base foliar, $0,2-0,7$ $\mathrm{cm}$ afastada da margem. Pedúnculo 1,6-5,5 cm compr., menor ou maior que o pecíolo, cilíndrico, carena ausente, verde, verde na frutificação. Espata $0,6-1,8 \times 0,15-0,3 \mathrm{~cm}$, oblonga ou lanceolada, não revoluta, ápice rostrado, membranácea, persistente, deflexa, patente ou ereta; margens se encontrando no pedúnculo em um ângulo geralmente agudo a obtuso; creme, verde-claro ou verde com margem rosa; decorrência no pecíolo ausente, raro presente com 0,1-0,2 cm compr. Espádice 0,7-2,4 × 0,1-0,2 cm, cilíndrico, creme-esverdeado em pré e pós-antese, creme-esverdeado ou verde-claro em antese; séssil a raro estipitado, estípite $0,2 \mathrm{~cm}$ compr., verde; 2-3 flores na espiral principal, 3-6 flores na espiral secundária, maturação acrópeta. Flores filetes $0,8-1 \times 0,6-1,3 \mathrm{~mm}$, anteras $0,2-0,4$ $\times 0,6-0,9 \mathrm{~mm}$; ovário $0,8-1 \times 0,9-1,1 \mathrm{~mm}$, placentação axial-apical, 2 óvulos por lóculo, eixo axilar do ovário com tricomas; estigma globoso a elíptico. Espádice em frutificação 1-5,1 × 1-1,8 $\mathrm{cm}$, ereto, alvo-vináceo, maturação das bagas acrópeta, homogênea ou dispersa. Bagas 4-7 × 4-7 $\mathrm{mm}$, globosas, alvas ou alvo-translúcidas na base e arroxeadas no ápice. Sementes elípticas, achatadas lateralmente, convexas em ambas as faces, alvas com o ápice verde.

Diferencia-se das demais espécies por ser geralmente epífita (ocasionalmente terrestre), ter catafilos desmanchando em fibras e persistentes recobrindo o caule, pontuações glandulares visíveis na lâmina foliar, inflorescências verdes a creme e bagas alvascentes. Floresce e frutifica o ano inteiro. 
É a espécie mais comum e amplamente distribuída de todos os Anthurium sendo Pouco Preocupante quanto ao seu estado de conservação. Distribui-se em florestas úmidas, em altitudes que vão do nível do mar até $2700 \mathrm{~m}$, nas Índias Ocidentais e porção Tropical da América Central e do Sul. No Brasil ocorre nos estados do Sudeste, e também no Acre, Amazonas, Bahia, Ceará, Distrito Federal, Paraná, Pernambuco, Santa Catarina. No Paraná ocorre em 11 municípios, em áreas de Floresta Ombrófila Densa de Terras Baixas, Submontana, Montana e Altomontana (Fig. 6), onde também é classificada como Pouco Preocupante, pois tem extensão de ocorrência maior que $20.000 \mathrm{~km}^{2}$, área de ocupação maior que $2.000 \mathrm{~km}^{2}$ e foi encontrado em mais de 20 localidades com um número grande de indivíduos.

No estudo taxônomico de Sheffer et al. (1980), foram reconhecidas duas subespécies: $A$. scandens subsp. scandens com estrutura genética poliplóide, espádice com 16-60 flores, 7-30 mm de comprimento em antese, lâmina foliar com ou sem pontuações glandulares na face adaxial e com 4-16 cm compr.; e A. scandens subsp. pusillum com estrutura genética diplóide, espádice com 5-12 flores, 2-10 $\mathrm{mm}$ de comprimento em antese, lâmina foliar com pontuações glandulares na face adaxial e 2-7,5 cm compr. Os espécimes analisados do Paraná apresentam as características da primeira subespécie.

Material selecionado: Adrianópolis, P.E. das Lauráceas, 20.II.2013, fl., L.C. Ferneda Rocha et al. 119 (UNOP). Antonina, Reserva Natural do Rio Cachoeira, 27.III.2003, fl. e fr., M. Borgo 2238 (MBM). Araucária, 26.VII.2005, fr., R.A. Kersten 1079 (UPCB). Campina Grande do Sul, Morro do Capivari Grande, 15.VIII.1985, fl. e fr., $J$. Cordeiro et al. 91 (MBM). Guaraqueçaba, 23.XI.2012, fl., L.C. Ferneda Rocha et al. 77 (UNOP). Guaratuba, Resgate de Flora, 7.IX.2013, fl. e fr., M.E. Engels 1560 (UNOP). Matinhos, Morro do Boi, 11.IX.1965, fl., G. Hatschbach 12751 (MBM). Morretes, Parque Nacional Saint Hilaire-Lange, 28.XI.2012, fl., L.C. Ferneda Rocha et al. 89 (UNOP;UPCB). Paranaguá, Parque Nacional Saint Hilaire-Lange, 27.XI.2012, fl., L.C. Ferneda Rocha et al. 85 (UPCB). Quatro Barras, Caminho do Itupava, 16.VI.2012, fl., M.E. Engels 398 (UNOP). São José dos Pinhais, RPPN Nhandara Guaricana, 21.IV.2013, fl., L.C. Ferneda Rocha et al. 157 (UNOP).

10. Anthurium sellowianum Kunth, Enumeratio Plantarum Omnium Hucusque Cognitarum, 3: 70. 1841. Fig. 5e-m; Apêndice 10a-i Epífita, terrestre, raro rupícola; caule ereto, entrenós $0,5-1 \mathrm{~cm}$ compr. Catafilos e profilos jovens verdes com a base creme ou alvescentes; senescentes palha ou castanhos, desmanchando em fibras, decíduos para a base do caule, 1,9-8,4 cm compr. Folhas simples; pecíolo 3,5-25,2 cm compr., verde ou verde com base alvescente; achatado ou levemente 1-sulcado, margem aguda a carenada adaxialmente; agudo ou obtuso, carena ausente a raro presente, sulco ausente abaxialmente; pontuações glandulares ausentes; geniculo $0,4-2,7 \mathrm{~cm}$ compr., espessura maior ou igual à do pecíolo, verde levemente mais claro que o pecíolo em material fresco e nigrescente em material seco, pontuações glandulares ausentes. Lâmina lanceolada a linear, 13,5-90,2 × 1,7-17 cm, ereta em relação ao caule, ápice agudo, acuminado, base obtusa, longo-cuneada a estreito-cuneada, cartácea, lustrosa, discolor, verde abaxialmente, margem inteira, pontuações glandulares ausentes. Nervura principal reta na base e no meio, obtusa a aguda no ápice, carena ausente, pouco proeminente a proeminente do meio para o ápice adaxialmente; obtusa a aguda, carenada, proeminente na base abaxialmente. Nervuras secundárias levemente impressas a impressas na face adaxial, evidentes a levemente proeminentes na face abaxial, 8-35 pares, nervura coletora inserida na base foliar, $0,2-$ 2,1 cm afastada da margem. Pedúnculo 11,5-68 $\mathrm{cm}$ compr., maior que o comprimento do pecíolo, cilíndrico ou anguloso, 1-5 carenado, verde a róseo ou verde-amarelado, verde na frutificação. Espata 6-24,2 × 0,5-1,8 cm, lanceolada, não revoluta, ápice rostrado, membranácea ou cartácea, persistente a raro decídua em frutificação, geralmente deflexa, raro patente ou ereta; margens se encontrando no pedúnculo em um ângulo agudo; verde a verde com margem roxa ou rósea; decorrência no pecíolo presente, $(0,5) 1,2-4 \mathrm{~cm}$ compr. Espádice 4,4-29,6 $\times 0,2-0,8 \mathrm{~cm}$, cilíndrico, roxo em pré-antese, roxo, vináceo ou roxo-acinzentado em antese, castanho em pós-antese; séssil a raro estipitado, estípite $0,2-$ $0,6 \mathrm{~cm}$ compr., verde, verde-arroxeado, vináceo; 3-7 flores na espiral principal, 4-11 flores na espiral secundária, maturação acrópeta a dispersa. Flores filetes $1,5-2,5 \times 0,5-0,7 \mathrm{~mm}$, anteras $0,7-0,9 \times 0,7-0,9 \mathrm{~mm}$; ovário 1,9-2,4 × 1-1,6 mm, placentação axial-apical, 1 óvulo por lóculo, eixo axilar do ovário com tricomas; estigma elíptico a globoso. Espádice em frutificação 9,2-28,8 × 2-2,6 $\mathrm{cm}$, ereto a pendente, roxo a castanho, maturação das bagas acrópeta, homogênea ou dispersa. Bagas 5,3-6,6 × 4-4,6 mm, globosas a oblongas, as vezes achatadas lateralmente pelas tépalas ficando 


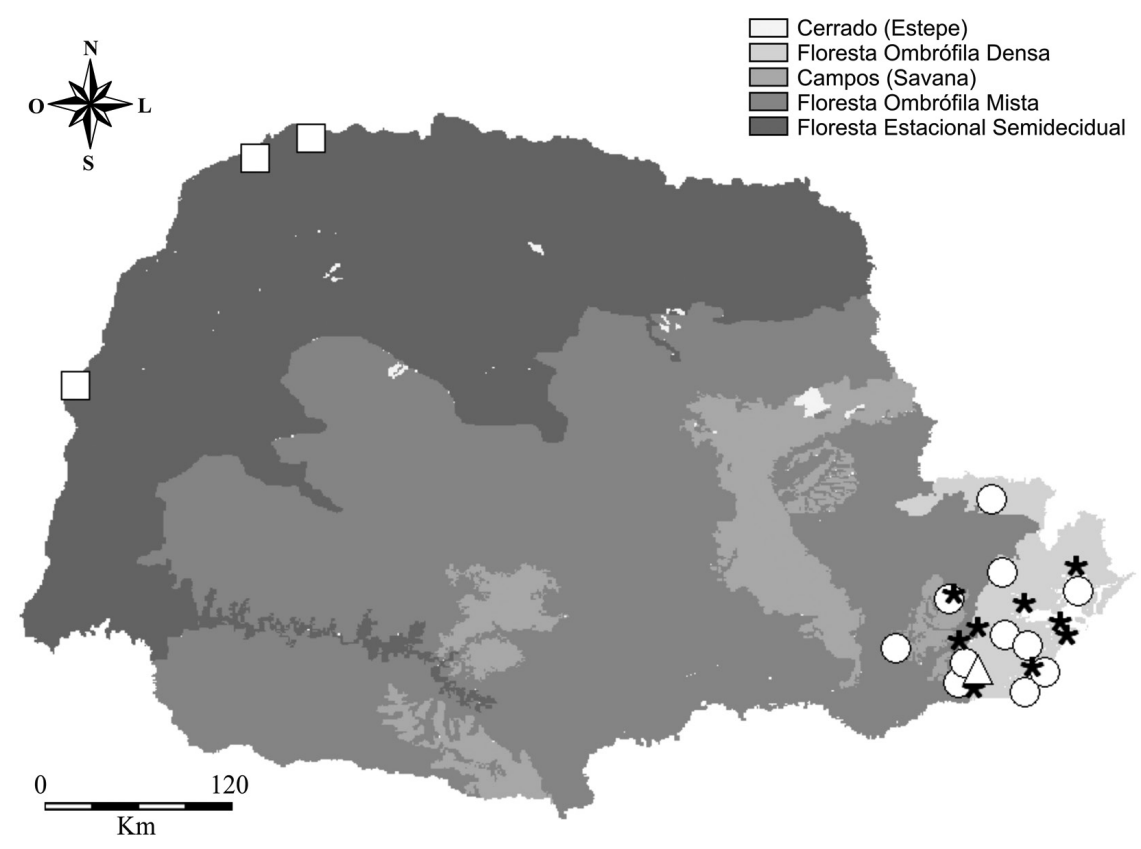

Figura 6 - Distribuição geográfica de A. scandens subsp. scandens (O), A. sellowianum ( ), A. sinuatum $(\square)$ e $A$. urvilleanum $(\triangle)$ no estado do Paraná.

Figure 6 - Geographic distribution of A. scandens subsp. scandens ( $)$ ), A. sellowianum ( $\star$ ), A. sinuatum $(\square)$ e A. urvilleanum $(\triangle)$ in Paraná state, Brazil.

levemente quadrangulares, verdes no ápice, verdes a alvas na base, as vezes translúcidas. Sementes arredondadas em ambas as faces, creme.

Diferencia-se das demais espécies por apresentar lâmina foliar ereta, com nervuras secundárias levemente impressas a impressas na face adaxial, evidentes a levemente proeminentes na face abaxial, pedúnculo até 5 carenado, espádice em frutificação podendo chegar até $28,8 \mathrm{~cm}$ compr. e bagas verdes. Floresce e frutifica o ano inteiro.

É endêmica do Brasil, onde ocorre nos estados de Minas Gerais, Paraná, Rio de Janeiro, Santa Catarina e São Paulo. No Paraná ocorre em nove municípios, em áreas de Floresta Ombrófila Densa Terras Baixas, Submontana e Montana (Fig. 6). Nos outros estados onde ocorre é classificada como Pouco Preocupante quanto ao seu estado de conservação, e no Paraná também, pois tem extensão de ocorrência maior que $20.000 \mathrm{~km}^{2}$, área de ocupação maior que $2.000 \mathrm{~km}^{2}$ e foi encontrado em mais de 20 localidades com um número grande de indivíduos.

A análise de vários espécimes demonstrou que a espécie é muito variável morfologicamente. A característica que se mantem nos exemplares é a nervura principal carenada na face abaxial e a margem do pecíolo carenado. Outros caracteres variam até no mesmo indivíduo, como a base da lâmina foliar e o formato do pecíolo abaxialmente. Sugerem-se estudos populacionais específicos para o melhor entendimento da delimitação taxonômica desta espécie.

Material examinado: Antonina, Reserva Natural Rio Cachoeira, 9.XII.2010, fl. e fr., L.G. Temponi 914 (UNOP). Campina Grande do Sul, 24.V. 1999, J.M. Cruz 114 (MBM). Guaraqueçaba, Reserva Natural Salto Morato, 6.V.2002, fr., A.S.L. Gatti et al. 757 (MBM). Guaratuba, Morro dos Perdidos, 29.VI.2013, fl., L.C. Ferneda Rocha et al. 226 (UNOP). Matinhos, 17.VIII.1959, fl., G. Hatschbach 6205 (MBM). Morretes, Serra da Graciosa, 31.VIII.2012, fl., M.E. Engels 507 (UNOP). Paranaguá, BR-407, 5.VII.2013, fl. e fr., L.C. Ferneda Rocha et al 241 (UNOP;UPCB). Pontal do Paraná, 28.IX.1990, fl., S.R. Ziller et al. 40 (EFC). São José dos Pinhais, RPPN Nhandara Guaricana, 21.IV.2013, fr., L.C. Ferneda Rocha et al. (UNOP 985).

11. Anthurium sinuatum Benth. ex Schott, Oesterreichisches Botanisches Wochenblatt, 7:318. 1857. Fig. 5n-r; Apêndice 11a-g

Hemiepífita, raro terrestre; caule geralmente escandente ou menos frequente ereto, entrenós $0,7-5 \mathrm{~cm}$ compr. Catafilos e profilos jovens verde a verde-alvascentes; senescentes castanhos, 
inteiros, raro levemente descompostos na base, persistentes no ápice do caule e decíduos para a base, 4-12,5 cm compr. Folhas compostas; pecíolo 29,7-76,7 cm compr., verde a verde com base nigrescente; cilíndrico a raro levemente achatado, carena ausente, 1-sulcado adaxialmente; pontuações glandulares ausentes; geniculo 0,5-1,3 $\mathrm{cm}$ compr., espessura maior que a do pecíolo, verde em material fresco, castanho em material seco, pontuações glandulares ausentes. Lâmina pedada, patente a deflexa em relação ao caule, 5-9-folíolos, sésseis ou com peciólulos de até $1,2 \mathrm{~cm}$ compr., folíolos 17,2-45,2 × 3,5-16,1 cm, ápice acuminado a apiculado, base estreito-cuneada a oblíqua, membranácea, fosca, discolor a levemente discolor, verde abaxialmente, margem sinuada, pontuações glandulares ausentes. Nervura principal obtusa na base, aguda no meio e ápice, carena ausente, levemente proeminente adaxialmente; obtusa, carena ausente, proeminente abaxialmente. Nervuras secundárias levemente impressas adaxialmente, proeminentes abaxialmente, 10-15 pares, nervura coletora inserida na base do folíolo ou um pouco acima, 0,4-1 cm afastada da margem. Pedúnculo 20,2-63,3 cm compr., mais da metade do comprimento do pecíolo, cilíndrico, carena ausente, verde, verde-amarelado na frutificação. Espata 8,2-26,5 × 1,2-3,7 cm, lanceolada, raro revoluta, ápice rostrado, membranácea, persistente a raro decíduo na frutificação, ereta a patente; margens se encontrando no pedúnculo em um ângulo agudo ou obtuso com o centro agudo; verde, verde-arroxeada ou verde-amarelada; decorrência no pecíolo presente, 0,7-3 cm compr. Espádice 6,5-25,2 × 0,5-1,7 cm, cilíndrico a levemente afilado no ápice, cor-de-palha a pardacento; estípite ausente; 4-8 flores na espiral principal, 7-12 flores na espiral secundária, sequência de maturação acrópeta. Flores filetes 1,6-1,9 × 1,4-1,5 mm, anteras $0,5-0,6 \times 0,8-1 \mathrm{~mm}$; ovário $1,6-1,9 \times$ 1,2-1,4 mm, placentação axial-apical, 1 óvulo por lóculo, eixo axilar do ovário com tricomas; estigma elíptico. Espádice em frutificação 12,5-40,3 × 1,3-2,7 cm, pendente, cor-de-palha a castanho, maturação das bagas acrópeta ou homogênea. Bagas 6,3-8,1 × 4,5-5,6 mm, obcônicas, as vezes achatadas lateralmente pelas tépalas ficando levemente quadrangulares, geralmente roxas a alvas na base, geralmente roxas, as vezes róseoescuras, raro castanho-alaranjadas no ápice. Sementes achatadas na face adaxial, arredondadas na face abaxial, castanho-avermelhadas.
Pode ser reconhecida pelo hábito hemiepífito, catafilos e profilos geralmente inteiros a levemente decompostos apenas na base, folíolos de margem sinuada e o pedúnculo com mais da metade do comprimento do pecíolo. Floresce e frutifica o ano inteiro.

Ocorre no Leste da América do Sul, da Guiana Francesa até o sul do Brasil. Pode ser encontrada no Amapá, Amazonas, Bahia, Ceará, Goiás, Minas Gerais, Paraná e São Paulo sendo classificada como Pouco Preocupante quanto ao seu estado de conservação. No Paraná foi registrada em apenas três municípios (Fig. 6), em áreas de Floresta Estacional Semidecidual, onde é classificada como Em Perigo, pois tem extensão de ocorrência menor que $5.000 \mathrm{~km}^{2}$, área de ocupação menor que 500 $\mathrm{km}^{2}$ e foi encontrado em três localidades, com um número pequeno de indivíduos. Além disso, as coletas no município de Guaíra foram realizadas há mais de 40 anos em uma área que foi alagada com a construção da Hidrelétrica de Itaipu, e não existe nenhum registro recente da espécie no município.

A. sinuatum é semelhante a $A$. kunthii Poepp. \& Endl., que possui margem dos folíolos inteira e espata deflexa, contra margem dos folíolos sinuada e espata ereta a raro patente em $A$. sinuatum. Semelhante também à $A$. clavigerum Poepp. da qual difere por ter espádice mais longo e espesso, e catafilos decompostos e decíduos, contra espádice mais curto e estreito, e catafilos inteiros e persistentes em $A$. sinuatum.

Material selecionado: Diamante do Norte, Estação Ecológica de Caiuá, 16.VII.2013, fl. e fr., L.C. Ferneda Rocha et al. 265 (UNOP;UPCB). Guaíra, Parque Nacional de Sete Quedas, 16.X.1962, fl., G. Hatschbach 40598 (MBM). São Pedro do Paraná, fl., 5.X.2006, M.A. Pagotto et al. 140 (HUEM).

12. Anthurium urvilleanum Schott, Prodromus Systematis Aroidearum, 459. 1860.

Fig. 5s-u; Apêndice 12a-e

Terrestre a raro epífita; caule ereto, entrenós 0,4-1,1 cm compr. Catafilos e profilos jovens verdes ou alvo-avermelhados; senescentes palha ou castanhos, desmanchando em fibras, geralmente decíduos para a base do caule, 2,8-5,7 cm compr. Folhas simples; pecíolo 3,7-33,5 cm compr., verde a verde com a base avermelhada; reto, sulco ausente, margem aguda a frequentemente carenada adaxialmente; agudo a obtuso, raro carenado abaxialmente; pontuações glandulares ausentes; geniculo 0,6-1,4 cm compr., espessura maior ou igual à do pecíolo, verde a esverdeado- 
vináceo em material fresco e nigrescente em material seco, pontuações glandulares ausentes. Lâmina lanceolada, 27,5-52,5 × 5,1-14,2 cm, ereta em relação ao caule, ápice acuminado, base estreito-cuneada, cartácea, lustrosa, discolor, verde abaxialmente, margem inteira, pontuações glandulares ausentes. Nervura principal obtusa na base, aguda do meio para o ápice, carena ausente, proeminente do meio para o ápice adaxialmente; aguda, carenada, proeminente da base para o ápice abaxialmente. Nervuras secundárias impressas a raro obscuras adaxialmente, evidentes ou proeminentes abaxialmente, 16-26 pares, nervura coletora inserida na base foliar, $0,5-0,9 \mathrm{~cm}$ afastada da margem. Pedúnculo 10,7-30 cm compr., maior que o comprimento do pecíolo, cilíndrico, 1-4 carenado, verde ou esverdeado-vináceo, esverdeado-avermelhado, esverdeado-amarelada, vináceo, verde na frutificação. Espata 6,1-9,2 $\times 0,8-0,9 \mathrm{~cm}$, lanceolada, não revoluta, ápice rostrado, membranácea, persistente a raro caduca, deflexa a raro patente; margens se encontrando no pedúnculo em um ângulo agudo; verde, raro com margem avermelhado-vinácea; decorrência no pecíolo, 0,4-2,4 cm compr. Espádice 6,5-9,4 $\times 0,3-0,5 \mathrm{~cm}$, cilíndrico, levemente afilando no ápice, roxo a vináceo em pré-antese, roxo a vináceo em antese, vináceo em pós-antese; séssil a raro estipitado, estípite $0,1-0,4 \mathrm{~cm}$ compr., verdeescuro; 5 flores na espiral principal, 7-8 flores na espiral secundária, maturação acrópeta. Flores filetes $1,5-1,9 \times 0,5-0,8 \mathrm{~mm}$, anteras $0,5-0,7 \times 0,8-$ 0,9 mm; ovário 1,9-2 × 0,8-0,9 mm, placentação axial-apical, 1 óvulo por lóculo, eixo axilar do ovário com tricomas; estigma elíptico ou globoso. Espádice em frutificação 10,5-12,3 × 0,6-0,8 cm, ereto, roxo a vináceo, maturação das bagas acrópeta a homogênea. Bagas 3,5-5,5 × 3-4 mm, obcônicas, vináceas no ápice, vináceas, verdes ou alvos na base quando maduros. Sementes não vistas.

Diferencia-se das demais espécies por ser geralmente terrestre, ter lâmina foliar lanceolada com nervuras secundárias impressas a raro obscuras adaxialmente, evidentes ou proeminentes abaxialmente e bagas vináceas. Encontrada com flores em abril e outubro, e com frutos em abril.

É endêmica do Brasil onde ocorre nos estados do Paraná, Rio de Janeiro, Santa Catarina e São Paulo. No Paraná foi encontrado apenas no município de São José dos Pinhais, em Floresta Ombrófila Densa Montana (Fig. 6). Como os dois locais onde a espécie foi coletada são muito próximos e não há um isolamento entre eles, estes foram considerados uma localidade. Apesar de ocorrer em outros estados onde é Pouco Preocupante quanto ao seu estado de conservação, para o Paraná é classificada como Criticamente em Perigo, pois tem extensão de ocorrência menor que $100 \mathrm{~km}^{2}$, área de ocupação menor que $10 \mathrm{~km}^{2}$, ocorre em apenas uma localidade com um número pequeno de indivíduos.

Material examinado: São José dos Pinhais, Castelhanos, 31.X.1996 fl., J.M. Silva et al. 1764 (RB); RPPN Nhandara Guaricana, 21.IV.2013, fl. e fr., L.C. Ferneda Rocha et al. 158 (UPCB;UNOP).

\section{Agradecimentos}

À REUNI-CAPES, a bolsa concedida a Lilien Cristhiane Ferneda Rocha; à Fundação de Amparo à Pesquisa do Estado de São Paulo - FAPESP (proc. 2010/17400-3) e ao Conselho Nacional de Desenvolvimento Científico e Tecnológico-CNPq (proc. 562240/2010-1), o apoio financeiro.

\section{Referências}

Angely, J. 1965. Flora Analítica do Paraná. Universidade de São Paulo, São Paulo. 728 p.

Berkenbrock, I.S. 2005. Fundamentos para Conservação de Anthurium coriaceum G. Don (Araceae), uma espécie potencialmente Ameaçada à extinção no Sul do Brasil. Dissertação de mestrado. Universidade Federal de Santa Catarina, Florianópolis. 67 p.

Boyce, P.C. \& Croat, T.B. 2012 - continuamente atualizado. The Überlist of Araceae, Totals for Published and Estimated Number of Species in Aroid Genera. Disponível em $<\mathrm{http}$ ://www.aroid. org/genera/120110uberlist.pdf $>$. Acesso em 25 de outubro de 2013.

Bridson, D. \& Forman, L. 2004. The Herbarium Handbook. 3 ed. The Royal Botanic Garden, London. 334 p.

Coelho, M.A.N. \& Mayo, S.J. 2007. Typifications of names of Brazilian taxa of Anthurium sect. Urospadix (Araceae). Taxon 56: 211-225.

Coelho, M.A.N. \& Temponi, L.G. 2013. Anthurium. In: Lista de Espécies da Flora do Brasil. Jardim Botânico do Rio de Janeiro. Disponível em $<$ http://floradobrasil.jbrj.gov.br/jabot/floradobrasil/ FB4912>. Acesso em 04 de março 2013.

Coelho, M.A.N.; Waechter, J.L. \& Mayo, S.J. 2009. Revisão Taxonômica das Espécies de Anthurium(Araceae) sect. Urospadix subsect. Flavescentiviridia. Rodriguésia 60: 799-864.

Croat, T.B. 1985. Collecting and preparing specimens of Araceae. Annals of Missouri Botanical Gardens 72: 252-258. 
Croat, T.B. 1994. Taxonomic status of Neotropical Araceae. Aroideana 17: 33-60.

Croat, T.B. \& Bunting, G.S. 1979. Standardization of Anthurium descriptions. Aroideana 2: 15-25.

Gonçalves, E.G. 2011. A new species of Anthurium (Araceae) from Paraná state, southern Brazil. Aroideana 34: 64-65.

Hatschbach, G.G. \& Ziller, S.R. 1995. Lista vermelha de plantas ameaçadas de extinção no estado do Paraná. Secretaria de Estado do Meio Ambiente/ GTZ, Curitiba. 139p.

IBGE - Instituto Brasileiro de Geografia e Estatística. 2010. Estado s: Paraná, Censo 2010. Disponível em $<$ http://www.ibge.gov.br/Estado sat/>. Acesso em 23 de maio de 2012.

IPNI - The International Plant Names Index. 2010. The Royal Botanic Gardens, Kew. Disponível em $<$ http://www.ipni.org/2010>. Acesso em 23 de maio de 2012.

IUCN. 2012. Guidelines for Application of IUCN Red List Criteria at Regional and National Levels: Version 4.0. Gland, Switzerland and Cambridge, UK. iii $+41 \mathrm{pp}$.

IUCN. Standards and Petitions Subcommittee. 2013. Guidelines for Using the IUCN Red List Categories and Criteria. Version 10. Prepared by the Standards and Petitions Subcommittee. Disponível em $<$ http://
jr.iucnredlist.org/documents/RedListGuidelines. pdf $>$. Acesso em 22 agosto 2013.

Madison, M. 1978. The species of Anthurium with palmately divided leaves. Selbyana 2: 239-282.

Mayo, S.J.; Bogner, J. \& Boyce, P.C. 1997. The genera of Araceae. Royal Botanical Garden, London. 370 p.

Radford, A.E.; Dickison, W.C.; Massey, J.R. \& Bell, C.R. 1974. Vascular Plant Systematics. Harper \& Row Publishers, New York, 891 p.

Reitz, P.R. 1957. Aráceas Catarinenses. Sellowia 8: 20-70.

Roderjan, C.V.; Galvão, F.; Kuniyoshi, Y.S. \& Hatschbach, G.G. 2002. As Unidades Fitogeográficas do Estado do Paraná, Brasil. Ciência \& Ambiente 24: 75-92.

Stearn, W.T. 2004. Botanical Latin. 4 ed. Timber Press, Inc., Portland, $546 \mathrm{p}$.

Sheffer, R.C.; Theobald, W.L. \& Kamemoto, H. 1980. Taxonomy of Anthurium scandens (Araceae). Aroideana 3: 86-93.

Temponi, L.G. 2006. Sistemática de Anthurium sect. Urospadix (Araceae). Tese de Doutorado. Universidade de São Paulo, São Paulo. 143 p.

Thiers, B. continuously updated. Index Herbariorum: A global directory of public herbaria and associated staff. New York Botanical Garden's Virtual Herbarium. Disponível em $<$ http://sweetgum.nybg. org/ih/>. Acesso em 03 fevereiro 2013.

Lista de coletores: P.R.P. Andrade s.n. (6); E. Barbosa 128 (1), 267 (6), 1328 (3), 1350 (3); J. Bianchi 66 (3); F.B. Becker 1 (6); M. Borgo 273 (9), 300 (3), 478 (3), 2019 (8), 2124 (9), 2366 (9); R.M. Britez s.n. (6), 1272 (9), 1380 (8); A.P. Cardozo 31 (6), 64 (10), 65 (3), 66 (7), 71 (9); J. Carneiro 523 (9); M.G. Caxambú 2110 (3); A.C. Cervi s. n. (9), 6354 (6), 6467 (9), 8795 (10), 9335 (2); J. Cordeiro 360 (6), 443 (6), 1513 (1); A.M.J. Corsi 457 (11), 605 (11), 609 (11); E.F. Costa 37 (6); L.T. Dombrowski 361 (6), 11397 (6); M.E. Engels 389 (3), 399 (3), 410 (9), 465 (2), 486 (3), 487 (9), 488 (8), 506 (9), 508 (3), 593 (3), 595 (3), 1512 (3), 1530 (9), 1573 (3), 1581 (9), 1610 (3); D.A. Estevan 1905 (3); G. Felitto 99 (1); L.C. Ferneda Rocha 41 (6), 42 (6), 43 (6), 44 (6), 45 (8), 46 (6), 47 (8), 48 (6), 49 (9), 50 (8), 51 (6), 52 (6), 53 (6), 56 (3), 79 (5), 82 (10), 83 (10), 86 (8), 92 (10), $111(2), 214$ (7), 223 (9), 225 (10), 232 (9), 239 (6), 242 (10), 243 (10), 274 (2), 275 (9), 277 (8), 278 (3), 280 (10), 281 (9), 286 (10), 287 (10), 312 (10); A.L.S. Gatti 85 (10), 96 (9), 207 (9), 321 (10), 354 (10), 354 (5), 470 (10), 519 (10), 620 (10); H.C.L. Geraldino 138 (10); C. Giongo 127 (6); G. Hatschbach 1023 (2), 1524 (9), 2273 (8), 2544 (10), 3265 (9), 4053 (6), 4859 (10), 6154 (3), 6208 (6), 6316 (9), 6486 (3), 6734 (5), 7087 (7), 7112 (9), 7116 (3), 7648 (1), 7792 (8), 8061 (3), 8158 (3), 8206 (10), 8317 (1), 9338 (11), 10129 (10), 10135 (6), 14755 (10), 15328 (10), 15331 (2), 16087 (7), 16655 (6), 17511 (10), 26776 (3), 27195 (3), 27593 (6), 27691 (10), 28534 (6), 32540 (6), 32599 (8), 32677 (9), 34351 (9), 35494(6), 37938 (10), 42500 (10), 42507 (6), 42540 (10), 43970 (9), 44388 (3), 44489 (10), 45266 (10), 45269 (8), 45429 (10), 45786 (9), 46080 (10), 46081 (8), 46086 (9), 46088 (10), 48891 (8), 48960 (10), 53265 (10), 57100 (3), 59448 (10), 62896 (10), 68885 (2), 69857 (10), 73833 (6); R. Hertel 455 (6), 456 (6); I. Isenhagen 359 (9); A.M. Janunzzi 870 (11); M. Kaehler 5 (2); B.D. Kellerman 55 (8); R. Kersten 408 (9), 720 (3), 1411 (3); C. Kozera 1093 (2), 1098 (2), 1108 (8), 1176 (2), 1200 (9), 1207 (6), 1298 (2), 1389 (2); L. Krieger 11097 (9), 11134 (10); L.M. Krul 17 (6); R. Kummrow 558 (6), 592 (10), 1152 (10), 1347 (6), 1350 (8), 2010 (3), 2973 (10); Y.S. Kunioshi 5138 (9), 5334 (11); P.H. Labiak 3117 (6); E. Lozano 637 (1); V. Marcilio 25 (6); E.M. Martins 4 (2); F.B. Matos 1205 (8); C. Michelon 1880 (3), 1881 (7); A.Y. Mocochinski 248 (1); J. T. Motta 628 (3), 772 (8), 924 (2), 928 (3), 998 (9), 1027 (2), 1942 (9); A.E. Muelbert 18 (10); P.I. Oliveira 652 (6); M.P. Petean s.n. (3), s.n. (8), s.n. (9), s.n. (10), s.n. (10), s.n. (10); M. Reginato 165 (3), 183 (7), 195 (3), 197 (7), 411 (3), 446 (3); R. Reitz 12115 (11); O.S. Ribas 117 (6), 184 (10), 546 (6), 1369 (7), 1612 (9), 4232 (1), 4329 (1); C.I.L.F. Rosa 208 (11), 237 (11); E.P. Santos 770 (7), 819 (7); C.M. Sakuragui 1295 (11); M.B. Scheer 516 (1); A.R. Silva 128 (3); J.M. Silva 1240 (6), 2525 (11), 3400 (3), 6127 (8), 6947 (6), 7628 (3); M.G. Silva 8 (10); S.M. Silva s.n. (6), s.n. (8), 25121 (3); C. Snak 281 (6); J.F. Stanicick s.n. (6); J. Sonehara 23 (6); W. S. Sousa s.n. (9); R. Tardivo 2 (10); L.G. Temponi 743 (6), 923 (8); G. Tessmann 908 (6); J.M.D. Torezan s.n. (6); S.R. Ziller 15 (10). 
